\title{
Characteristics of Precipitation Features and Annual Rainfall during the TRMM Era in the Central Andes
}

\author{
KAREN I. MOHR \\ Mesoscale Atmospheric Processes Laboratory, NASA Goddard Space Flight Center, Greenbelt, Maryland \\ DANIEL SLAYBACK AND KARINA YAGER \\ Biospheric Sciences Laboratory, NASA Goddard Space Flight Center, and Science Systems and Applications, Inc., \\ Greenbelt, Maryland
}

(Manuscript received 1 October 2013, in final form 14 January 2014)

\begin{abstract}
The central Andes extends from $7^{\circ}$ to $21^{\circ} \mathrm{S}$, with its eastern boundary defined by elevation $(1000 \mathrm{~m}$ and greater) and its western boundary by the coastline. The authors used a combination of surface observations, reanalysis, and the University of Utah Tropical Rainfall Measuring Mission (TRMM) precipitation features (PF) database to understand the characteristics of convective systems and associated rainfall in the central Andes during the TRMM era, 1998-2012. Compared to other dry (West Africa), mountainous (Himalayas), and dynamically linked (Amazon) regions in the tropics, the central Andes PF population was distinct from these other regions, with small and weak PFs dominating its cumulative distribution functions and annual rainfall totals. No more than $10 \%$ of PFs in the central Andes met any of the thresholds used to identify and define deep convection (minimum IR cloud-top temperatures, minimum $85-\mathrm{GHz}$ brightness temperature, maximum height of the $40-\mathrm{dB} Z$ echo). For most of the PFs, available moisture was limited $(<35 \mathrm{~mm})$ and instability low $\left(<500 \mathrm{~J} \mathrm{~kg}^{-1}\right)$. The central Andes represents a largely stable, dry to arid environment, limiting system development and organization. Hence, primarily short-duration events ( $<60 \mathrm{~min}$ ) characterized by shallow convection and light to light-moderate rainfall rates $\left(0.5-4.0 \mathrm{~mm} \mathrm{~h}^{-1}\right)$ were found.
\end{abstract}

\section{Introduction}

Analyses of the characteristics of convection observed by microwave sensors both in the global tropics (e.g., Mohr and Zipser 1996; Nesbitt et al. 2000; Toracinta et al. 2002; Cecil et al. 2005; Liu et al. 2007, 2008; Liu 2011) and in regional studies (e.g., Mohr 2004; Hirose and Nakamura 2005; Nicholls and Mohr 2010; Rasmussen and Houze 2011; Romatschke and Houze 2011, 2013; $\mathrm{Xu}$ 2013) have shown that parameters such as 85- or 37-GHz ice scattering signatures, lightning flash rate, the width of convective cores, and the maximum height of the $40-\mathrm{dB} Z$ echo derived from space-based microwave imager and/or radar observations are useful for assessing the characteristics such as location, frequency, size, intensity, and morphology of organized

Corresponding author address: Karen I. Mohr, Mesoscale Atmospheric Processes Laboratory, Code 612, NASA Goddard Space Flight Center, Greenbelt, MD 20771.

E-mail: karen.mohr-1@nasa.gov convective systems. Regional studies have provided important details on the unique characteristics of convective systems within their study sites that cannot be discussed at length in global studies. In this study, we used both surface and space-based datasets to analyze the convective systems of the central Andes. The Andes extend from the west coast of Colombia $\left(10^{\circ} \mathrm{N}\right)$ to the southern tip of Chile $\left(53^{\circ} \mathrm{S}\right)$. In southern Peru and Bolivia, the Altiplano, a high plateau over $3000 \mathrm{~m}$, splits the orography into separate eastern and western cordilleras. Both frozen and liquid precipitation types occur in this region, affecting the mass balance of approximately $90 \%$ of the world's remaining tropical mountain glaciers (L'Hôte et al. 2005; Mark 2008; Jomelli et al. 2009; Rabatel et al. 2013).

The similarity of large-scale moisture transport regimes and thus the uniformity of seasonality drive the choices of our study region boundaries. The location and terrain of the study region are depicted in Fig. 1. In the reviews of Andean climate, the zonal extent of the central Andes is $7^{\circ}-21^{\circ} \mathrm{S}$, the region dominated by upper-level easterlies October to April (Cook 2009; Garreaud 2009; Garreaud

DOI: 10.1175/JCLI-D-13-00592.1 


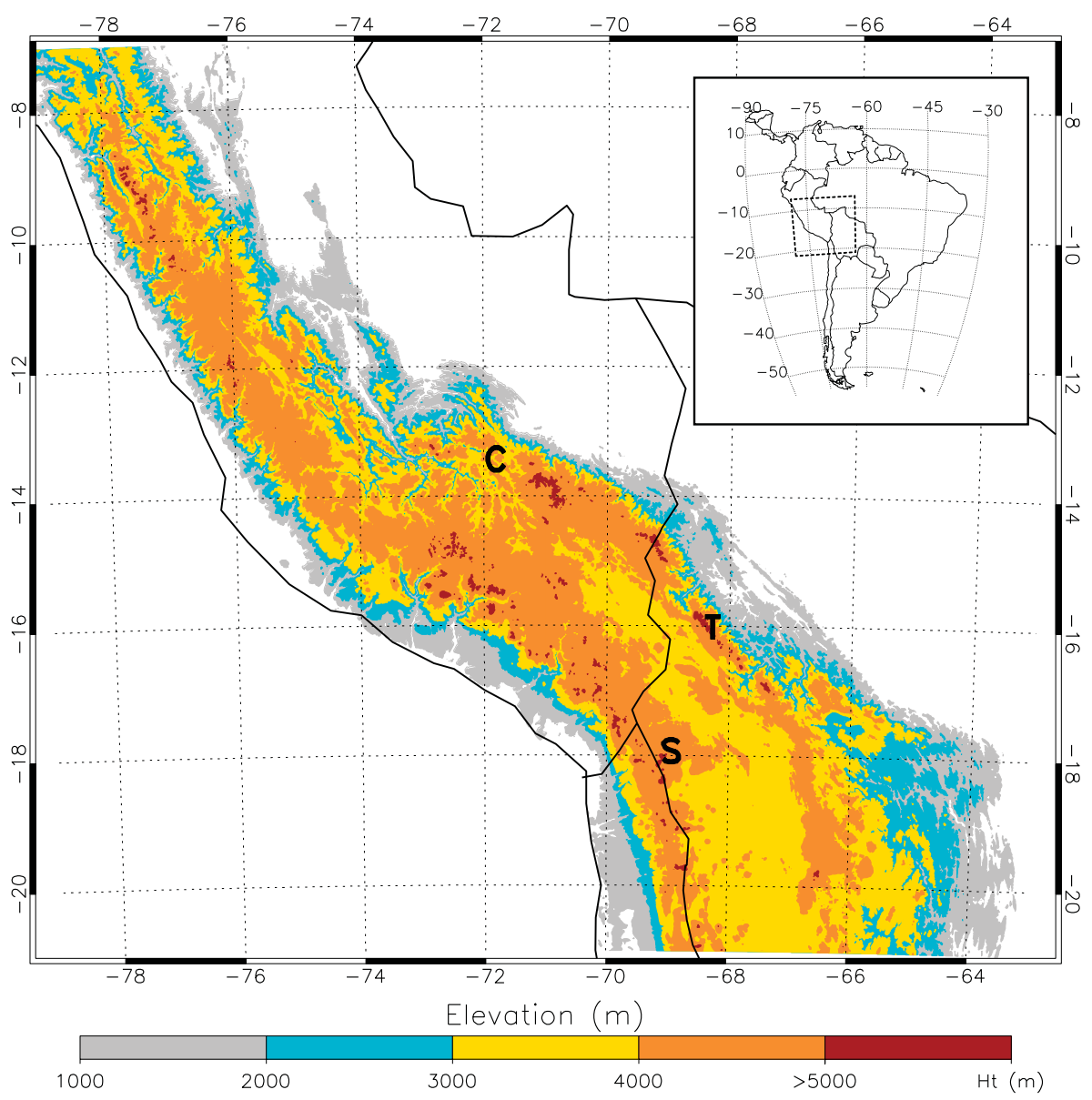

FIG. 1. The location and terrain of the study region. Only elevations over $1000 \mathrm{~m}$ are contoured in 1000-m increments. Our field sites in Bolivia are plotted: $\mathrm{T}$ for Tuni in the east (Cordillera Real) and S for Nevado Sajama in the west (Cordillera Occidental). The Altiplano is the $3000-4000 \mathrm{~m}$ (yellow) plateau between Tuni and Sajama. The C is Cuzco, Peru, mentioned several times in our discussion as the study site of Perry et al. (2014).

et al. 2009). Elevation (terrain $>1000 \mathrm{~m}$ ) defines the eastern boundary, and the western boundary is the coastline. Here, we not only examine the characteristics of organized convective systems in the central Andes but also provide context for our results by comparing the central Andes to other tropical regions. The lengthy (1998-2012) observational record of the Tropical Rainfall Measuring Mission (TRMM) satellite makes interregional, multiyear comparisons possible.

During austral summer, the southern shift of the ITCZ and the westward enhancement of moist flow around the South Atlantic anticyclone produce the southern Atlantic convergence zone (SACZ). The position and intensity of the SACZ and northeasterly tropical trade winds govern the intraseasonal variability of deep convection over the Amazon basin and the formation of the South American low-level jet (SALLJ) on the eastern edge of the central Andes (Nogués-Paegle and Mo 1997; Liebmann et al. 1999; Carvalho et al. 2004; Liebmann et al. 2004; Nieto-Ferreira and Rickenbach 2011; Espinoza et al. 2012). The moisture transport associated with the SALLJ extends to about $700 \mathrm{hPa}$, approximately $3000 \mathrm{~m}$, although the majority of the moisture transport is below $1000 \mathrm{~m}$ (Vera et al. 2006; Salio et al. 2007; Giovannettone and Barros 2009).

Above and west of the eastern 1000-m height contour, the most significant dynamical feature is the Bolivian high. It develops in the upper troposphere (200$300 \mathrm{hPa}$ ) as a Rossby wave response to the latent heat release from deep convection in the Amazon basin and is prominently located over Bolivia (Lenters and Cook 1997; Chen et al. 1999; Lenters and Cook 1999; Garreaud et al. 2003; Vuille and Keimig 2004). The cyclonic circulation that develops around the Bolivian high during the wet season produces upper-level easterlies over the central Andes, thus transporting Amazonian moisture westward. If the SACZ is weaker and/or shifted northeastward relative to its climatological mean, the Bolivian 
high and its associated easterly flow regime are replaced by a westerly flow regime that curtails moisture transport from Amazonian sources and results in negative precipitation anomalies over the central Andes (Garreaud 1999; Lenters and Cook 1999; Vuille 1999; Garreaud 2000). During the transition to the dry season in April and May, the weakening SACZ and the northward shift of the ITCZ in austral winter allows an upper-level westerly jet to migrate poleward, and easterly flow into the central Andes largely ceases.

The background environment for convection is thus established by the moisture transport and the downward mixing of momentum from the easterly flow around the Bolivian high. These processes can enhance upslope flow from lowland valleys, promoting convective initiation locally (Garreaud 1999, 2000; Egger et al. 2005; Falvey and Garreaud 2005; Bendix et al. 2006). In the Altiplano, the intense heating over the arid plains can greatly enhance this effect around the front ranges (Garreaud 2000; Garreaud et al. 2003). Troughs associated with extratropical waves occasionally penetrate the tropical latitudes, setting up a temporary southwesterly moisture transport and enhancing mesoscale to synopticscale convergence zones along the west coast (Garreaud and Wallace 1998; Seluchi and Marengo 2000; Siqueira and Toledo Machado 2004; Seluchi et al. 2006). Trajectory analysis by Perry et al. (2014) revealed that $95 \%$ of precipitation events occurring in Cuzco, Peru (Fig. 1; $13.53^{\circ} \mathrm{S}, 71.97^{\circ} \mathrm{W}, 3400 \mathrm{~m}$ ), on the eastern side of the central Andes were associated with moisture transport from nearby Amazon basin source regions and 5\% from weak southerly flow regimes of extratropical origin.

Remote sensing and modern reanalysis datasets make it possible to examine both the characteristics of organized convection and their environments in regions of complex terrain. For the humid, Amazon-facing front range, there are space- and ground-based radar studies that discuss the diurnal cycle (Bendix et al. 2006; Rapp and Silman 2012), convective development (Bendix et al. 2009; Rollenbeck and Bendix 2011; Romatschke and Houze 2013), and extreme events (Romatschke and Houze 2010; Rasmussen and Houze 2011). For the subhumid to arid highlands of our study region, the discussion is limited to the mechanisms of the initiation of deep convection (Garreaud 2000; Garreaud et al. 2003; Giovannettone and Barros 2009) and the intraseasonal and/or interannual variability of total rainfall and convective activity particularly as they relate to $\mathrm{El}$ Niño/La Niña (e.g., Ronchail and Gallaire 2006; Lavado Casimiro et al. 2012; Thibeault et al. 2012).

In this paper, we seek to contribute to a limited knowledge base on the characteristics of precipitating events in the central Andes. We analyze TRMM-observed precipitation features (PFs) for 1998-2012, reanalysis, and surface observations to derive their spectra of size, intensity, echo-top height, diurnal cycle, rainfall rates, and prestorm environments. We also consider variability in system characteristics among different precipitation climate zones in the study region and how the characteristics of events in the central Andes compare to other tropical regions. Our paper is organized into six sections, with three sections devoted to results and analysis as follows: section 3 , precipitation datasets; section 4, TRMM precipitation features; and section 5 , the prestorm environment.

\section{Data and methods}

\section{a. Space-based and surface datasets}

For this study, we derived a database of PFs in the central Andes from the master TRMM precipitation features database (version 7) for 1998-2012. The University of Utah Precipitation Measuring Mission Science Group compiles this database from observations from the four sensors on board TRMM: the TRMM Microwave Imager (TMI), precipitation radar (PR), Lightning Image Sensor (LIS), and Visible and IR Scanner (VIRS). The analysis of orbital resolution data begins with the clustering of contiguous PR-derived near-surface raining pixels (resolution $5 \mathrm{~km}$ ), so that the number of separate raining features in each PR swath is reduced to a minimum. A PF is recorded for each cluster, and measurements from the other instruments (with different footprints) are collocated and grouped with the PF using the adjacent-pixel method and parallax correction described in Liu et al. (2008). Each PF record includes center location, time, and elevation, as well as a long list of parameters derived from the four TRMM sensors that are relevant to studying precipitating clouds.

We obtained rain gauge data from our own field sites, located near the community of Tuni, Bolivia $\left(16.67^{\circ} \mathrm{S}\right.$, $68.13^{\circ} \mathrm{W}$ ) and by Nevado Sajama (henceforth Sajama; $\left.18.11^{\circ} \mathrm{S}, 68.89^{\circ} \mathrm{W}\right)$, an extinct stratovolcano and the highest peak in Bolivia $(6542 \mathrm{~m})$. Tuni, in the east (Cordillera Real), and Sajama, in the west (Cordillera Occidental), are marked on Fig. 1. The field sites have recording rain gauges installed in valleys below the local permanent snow lines (Table 1). We obtained event counts, event amounts, rain rates, and event durations from the recording gauge data at Tuni and Sajama. The installed gauges are tipping-bucket-type gauges, the HOBO Data Logging Rain Gauge (RG3) from Onset Computer Corporation. Tipping-bucket tips were converted to tip minutes (i.e., minutes where tips occurred), and then to amounts $(1 \mathrm{tip}=0.254 \mathrm{~mm})$. Rainfall rates were derived from linear interpolation of the tip minutes (Wang et al. 2008). Event duration was calculated from the first tip to 
TABLE 1. Elevation and data availability for the recording rain gauges installed at Tuni and Sajama.

\begin{tabular}{lcc}
\hline \hline Field site & Elevation $(\mathrm{m})$ & Data availability \\
\hline Tuni & 4689 & 27 Oct 2011-9 May 2012 \\
Sajama & 4544 & 13 Mar 2012-20 Oct 2012 \\
\hline
\end{tabular}

the last tip, where the last tip was defined as no more than $1 \mathrm{~h}$ from the previous tip but more than $1 \mathrm{~h}$ to the next tip. We defined a multitip rainfall event as at least two tips spaced no more than $1 \mathrm{~h}$ apart. Although half-hour spacing was used in African environments dominated by deep convection (Cosgrove and Garstang 1995; Balme et al. 2006; Haile et al. 2011), the light rain rates derived from the recording gauge data at Tuni and Sajama suggested a more generous definition of "event" than deep convection-dominated sub-Saharan Africa. At Tuni, 234 of 365 observed events were multitip (65\%), and at Sajama 18 of 39 events (46\%) were multitip.

In addition to point observations, we used gridded data products in the analysis. The 1 -arc-min $\left(\sim 0.01^{\circ}\right)$ gridded elevations/bathymetry for the world (ETOPO1) global relief model is available from the National Oceanic and Atmospheric Administration (NOAA) National Geophysical Data Center. It integrates topographic and bathymetric information into a single digital file and is easily analyzed for slope and aspect with geographic information system (GIS) software ArcGIS from ESRI. For mapping seasonal rainfall across the study region, we relied on the multisatellite TRMM 3B43 (version 7) gridded monthly means at $0.25^{\circ}$ resolution. Since we use the PF database for examining specific cases rather than gridded rainfall products, we use the 3B43 for the task of depicting seasonality and regional-scale rainfall gradients.

\section{b. Parameters in the PF database}

Liu et al. (2008) detail how data from TRMM sensors are combined to create the PF database. For the 85and $37-\mathrm{GHz}$ channels, they use polarization-corrected brightness temperatures to screen out background effects over cold surfaces. Their paper is also a useful summary and demonstration of parameters in the database that are physically meaningful metrics for evaluating the characteristics of organized convection. These metrics include system area, rainfall rates, lightning flash rate (LFR), maximum 20-dBZ echo-top height (MAXHT20) and 40-dBZ echo-top height (MAXHT40), the minimum $85-\mathrm{GHz}$ polarization-corrected brightness temperature (MIN85), and the minimum IR cloud-top temperature (MINIR). The MIN85, LFR, and the echo tops are closely related to the intensity of convective updrafts through the troposphere, particularly in the mixed phase region, as radars and the high-frequency $(37 \mathrm{GHz}$ and higher) channels of passive microwave imagers are particularly sensitive to scattering by large ice particles. The MINIR reflects the penetration of updrafts into the upper troposphere and beyond. In the TRMM literature, screening PFs for size is typically performed to eliminate small PFs that, although numerous, are not expected to contribute significantly to regional rainfal totals. Global studies such as Liu et al. (2008) set a screen of $200 \mathrm{~km}^{2}$, eight $5 \mathrm{~km} \times 5 \mathrm{~km}$ PR pixels, although regional studies can have screens as small as $64 \mathrm{~km}^{2}$ (West Africa; Mohr 2004) or as large as $400 \mathrm{~km}^{2}$ (East Asia; Xu 2013) to reflect regional deviations from the global mean. Because of the recording gauge data available to us, we broke with this practice. Most of our analysis includes PFs of all sizes occurring in the study region. We compare screened and unscreened PFs only in our analysis of LFR.

Environmental variables (temperature, geopotential height, wind, total precipitable water, and humidity) at 6-h and $2.5^{\circ}$ resolution from the National Centers for Environmental Prediction (NCEP) reanalysis are packaged with each PF. Because of the complexity of the terrain in our study region, we chose instead to use the NCEP Climate Forecast System Reanalysis (CFSR) at 6-h and $0.5^{\circ}$ resolution for both state variables and derived parameters such as convective available potential energy (CAPE). Bao and Zhang (2013) show that the newer generation CFSR reanalysis has smaller rootmean-square error and bias than the older generation NCEP reanalysis. To represent the prestorm environments, we find the CFSR grid cell containing each PF's centroid coordinates and then select the closest previous period. For a PF at 1031 UTC, 0600 UTC is selected, and for a PF at 0022 UTC, 0000 UTC is selected.

\section{Analysis of precipitation datasets}

\section{a. Precipitation climatology}

Figure 2 contains map views from the 3B43 rainfall product of the monthly mean daily rainfall $\left(\mathrm{mm} \mathrm{day}^{-1}\right)$ for the beginning (October), peak (January), and end (April) of the wet season and the peak of the dry season (July). In all panels of Fig. 2, there is a general east to west decreasing gradient of rainfall, with some adjustment by altitude. Despite similar altitudes, Tuni has 2-3 times more rainfall per day and per year than Sajama. The secondary role of altitude can be seen more clearly over the highest peaks in southern Peru, where there is a local maximum in January $(6-8 \mathrm{~mm}$ contour), but fading in size and contrast by April. The white 1000-m contour on Fig. 2 clarifies the choice of this contour as the PF database eastern boundary. There is a visible contrast in the amount and seasonality of the precipitation over the highlands west of the 

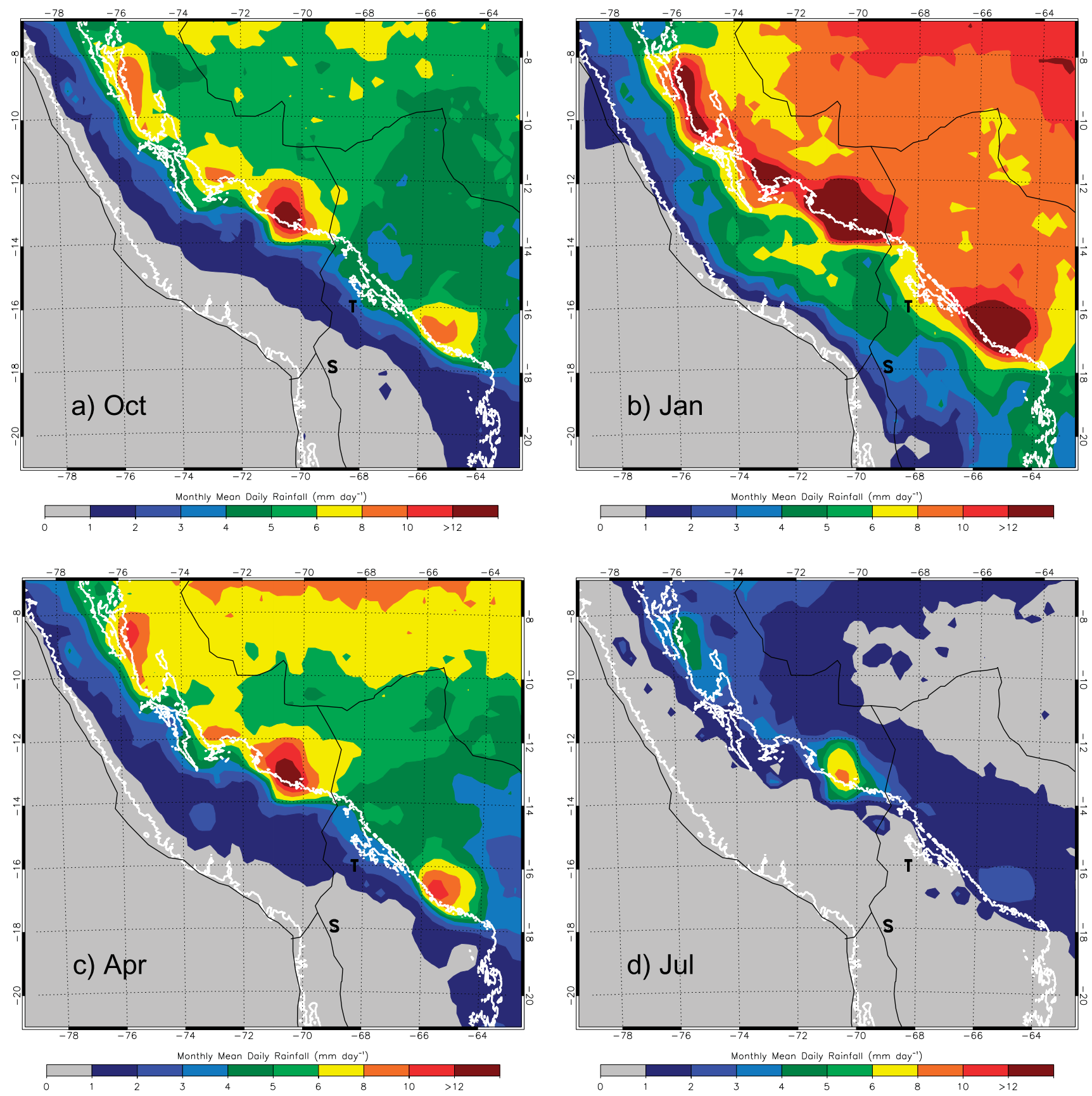

FIG. 2. Map views from the 3B43 rainfall product of the monthly mean daily rainfall (mm day ${ }^{-1}$ ) for (a) October, (b) January, (c) April, and (d) July. The "T" and "S" illustrate the differences in precipitation climate between Tuni and Sajama despite similar altitudes. The white contour highlights the 1000-m elevation line.

1000-m contour versus in the foothills and lowlands to the east. The high instability and abundant moisture transport due to the SALLJ makes the development of large, well-organized mesoscale convective systems (MCSs) possible in the foothills (Romatschke and Houze 2010). Similar dynamics and large MCSs are features of other alpine foothill regions such as the front range of the Himalayas (Romatschke and Houze 2011; Houze 2012).
Figure 3 is a map of the mean annual rainfall $(\mathrm{mm})$ from the 3B43 product (1998-2012). The levels are based on the regional histogram breakpoints (Jenks method) calculated in ArcGIS, and the color scheme was chosen to facilitate comparisons among the figures in the paper. In Fig. 2b (January) and Fig. 3, the effect of altitude during the period of strongest easterly moist transport can be seen most clearly over the high peaks of southern Peru. During the TRMM era, the areas around 


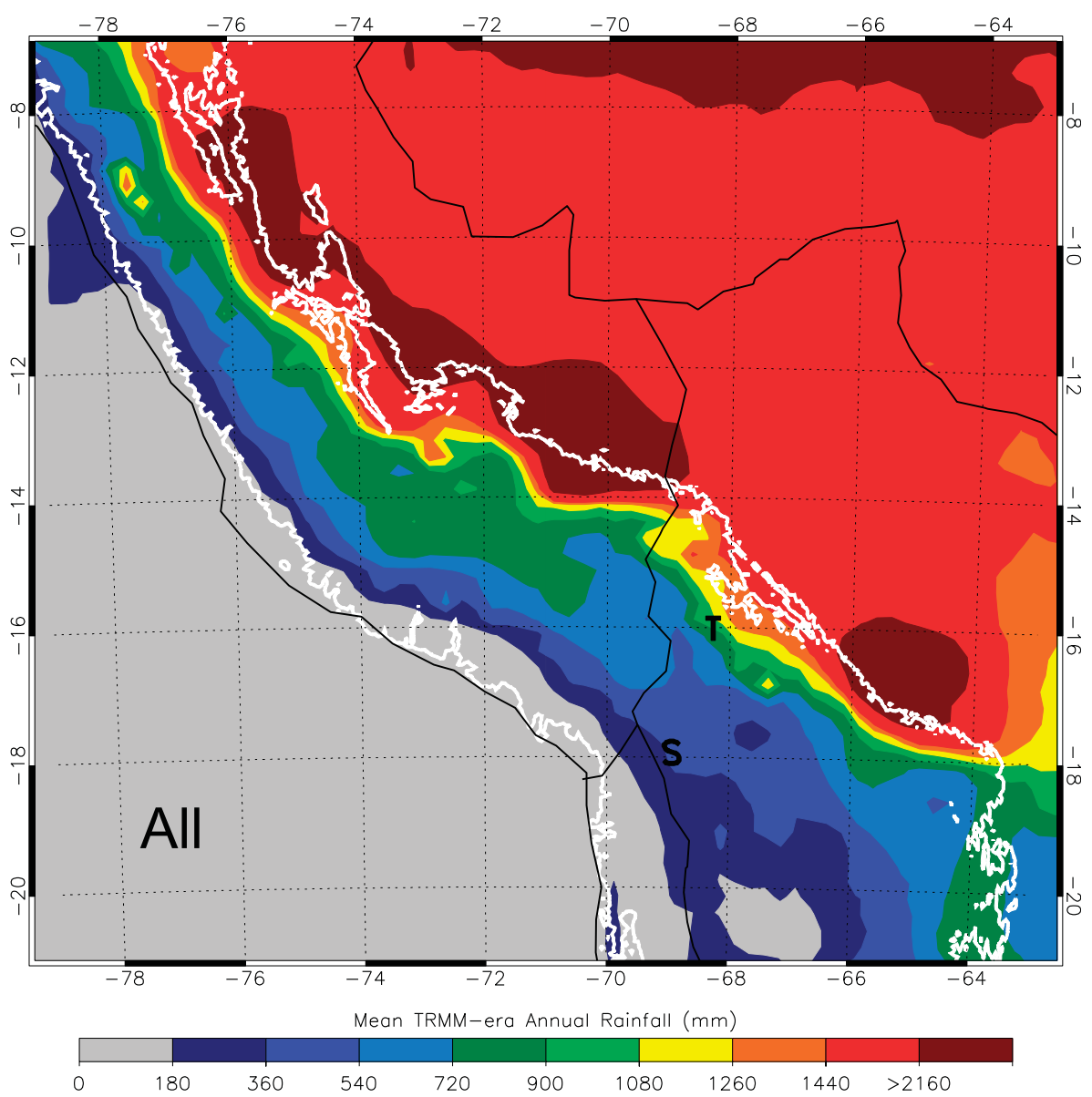

FIG. 3. The mean annual rainfall (mm) from the 3B43 product (1998-2012). The levels are multiples of $180 \mathrm{~mm}$ based on the GIS-derived breakpoints in the regional histogram. The "T" and "S" illustrate the differences in annual totals between Tuni and Sajama despite similar altitudes. The white contour highlights the 1000-m elevation line.

Tuni and Sajama have the same response to ENSO, with negative anomalies in El Niño and positive in La Niña, varying as much as $40 \%$ from year to year, but more typically varying by $10 \%-15 \%$ (Lavado Casimiro et al. 2012; Thibeault et al. 2012).

\section{b. Rainfall events in the recording rain gauge data}

The difficulty of obtaining and maintaining recording rain gauge sites in the study region due to distance and weather resulted in a limited time series (Table 1). However, there is a nearly complete wet season at the Tuni gauge, and the Sajama gauge provides a meaningful view of the end of its wet season. Figure $4 \mathrm{a}$ contains the time series of daily rainfall $(\mathrm{mm})$ for both sites. For both sites, most of the daily totals in Fig. 4a are less than $10 \mathrm{~mm} \mathrm{day}^{-1}$. The Sajama gauge has a similar sequence of wetter and drier periods as the Tuni gauge in March and April. However, the typically lower accumulations at Sajama are delivered in 1-2 events per day versus $2-4$ events per day that occur at
Tuni. Multiple events at Tuni result in a broad diurnal cycle (Fig. 4b) with most events occurring around noon to the early evening hours, with very little rainfall occurring around midnight or in the early morning. In contrast, the most significant rainfall identified by Perry et al. (2014) for Cuzco occurred around midnight, similar to the nocturnal foothill events in Romatschke and Houze (2013).

In Fig. 5, the event average rain rates are the average of the 1-min rain rates during the duration of multitip events. Figures $5 \mathrm{a}$ and $5 \mathrm{~b}$ are scatter diagrams for Sajama and Tuni, respectively, in which events are grouped by month. There is an expected decline in intensity with duration, although there is no detectable difference in the intensity or duration of events with respect to month. At both Tuni and Sajama, more than $50 \%$ of the events are less than $3 \mathrm{~mm} \mathrm{~h}^{-1}$ and below $60 \mathrm{~min}$ in duration, and more than $90 \%$ are below $6 \mathrm{~mm} \mathrm{~h}^{-1}$ and $200 \mathrm{~min}$. Tuni has events throughout the wet season greater than $2 \mathrm{~h}, 15 \%$ of which lasted more than 

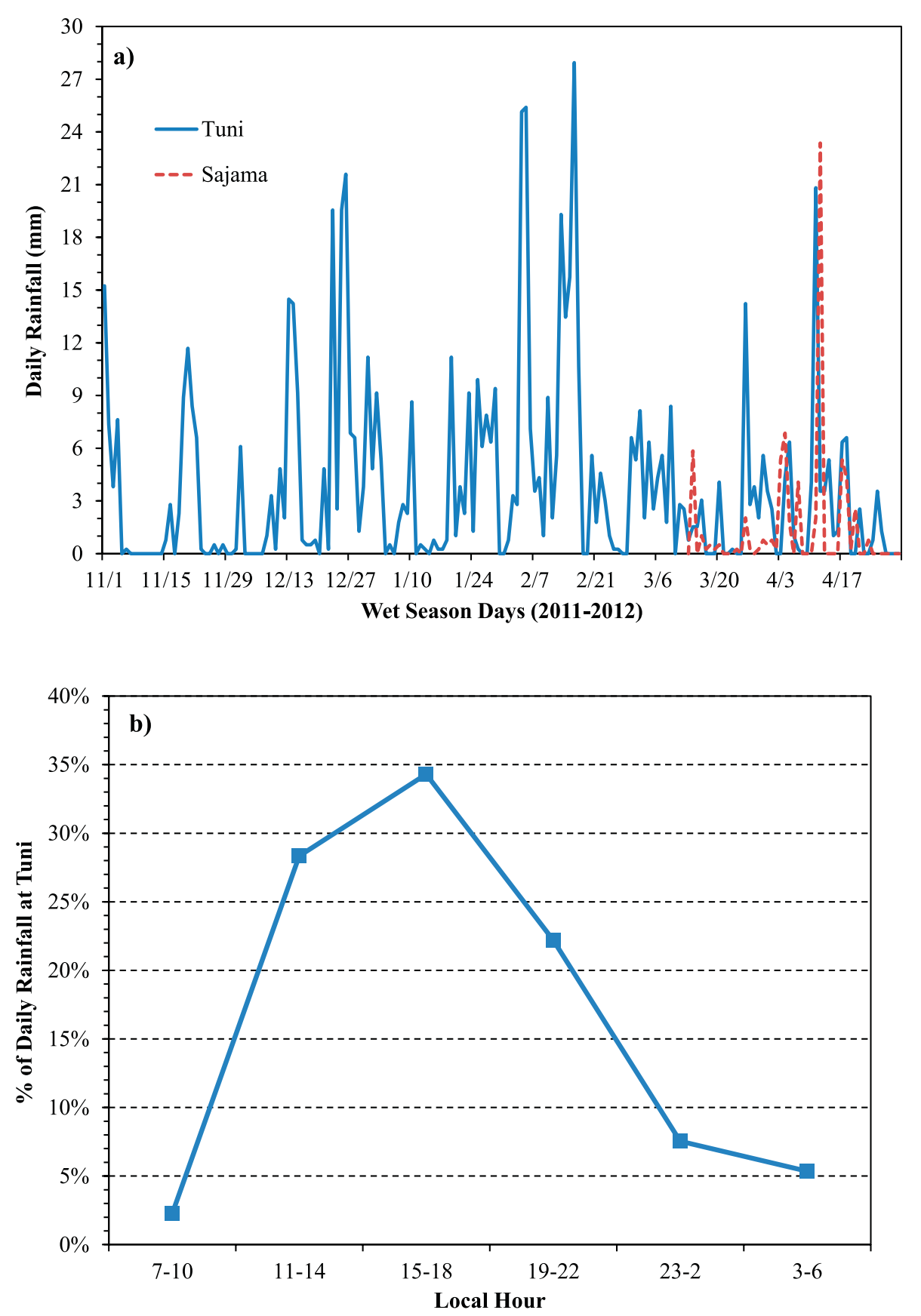

FIG. 4. (a) A time series of daily rainfall ( $\mathrm{mm}$ ) for Tuni (blue, solid line) and Sajama (red, short dashes) from November 2011 through April 2012. (b) The diurnal cycle for Tuni, grouped by 4-h blocks due to the limited time series. The total rainfall at Tuni for this time period was $708 \mathrm{~mm}$.

$3 \mathrm{~h}$. However, the likelihood of events averaging greater than $10 \mathrm{~mm} \mathrm{~h}^{-1}$ is comparably low $(<10 \%)$. Figure $5 \mathrm{c}$ compares event average rain rates at Tuni to their contribution to rainfall in the 2011/12 wet season. The distribution peaks in the $1-2 \mathrm{~mm} \mathrm{~h}^{-1}$ bin, with the majority of the rainfall contributed by events less than $3 \mathrm{~mm} \mathrm{~h}^{-1}$ and $90 \%$ by events less than $7 \mathrm{~mm} \mathrm{~h}^{-1}$.

Both Figs. 4 and 5 depict rainfall regimes characterized by sporadic, mostly light and short $(<60 \mathrm{~min})$ rainfall events. At both Tuni and Sajama, days in the top $25 \%$ of daily rainfall $\left(>5 \mathrm{~mm} \mathrm{day}^{-1}\right)$ are typically characterized by one or more long duration events $(>60 \mathrm{~min})$ with light average rainfall rates $\left(<3 \mathrm{~mm} \mathrm{~h}^{-1}\right)$ rather than shorter, heavier events $\left(>10 \mathrm{~mm} \mathrm{~h}^{-1}\right)$. All but one of the long duration events at Tuni had 1-min rain rates less than $10 \mathrm{~mm} \mathrm{~h}^{-1}$, and the most intense long duration event at Tuni (13 February; $68 \mathrm{~min}, 11.88 \mathrm{~mm} \mathrm{~h}^{-1}$ ) had 1-min rain rates from 0 to $15 \mathrm{~mm} \mathrm{~h}^{-1}$. 

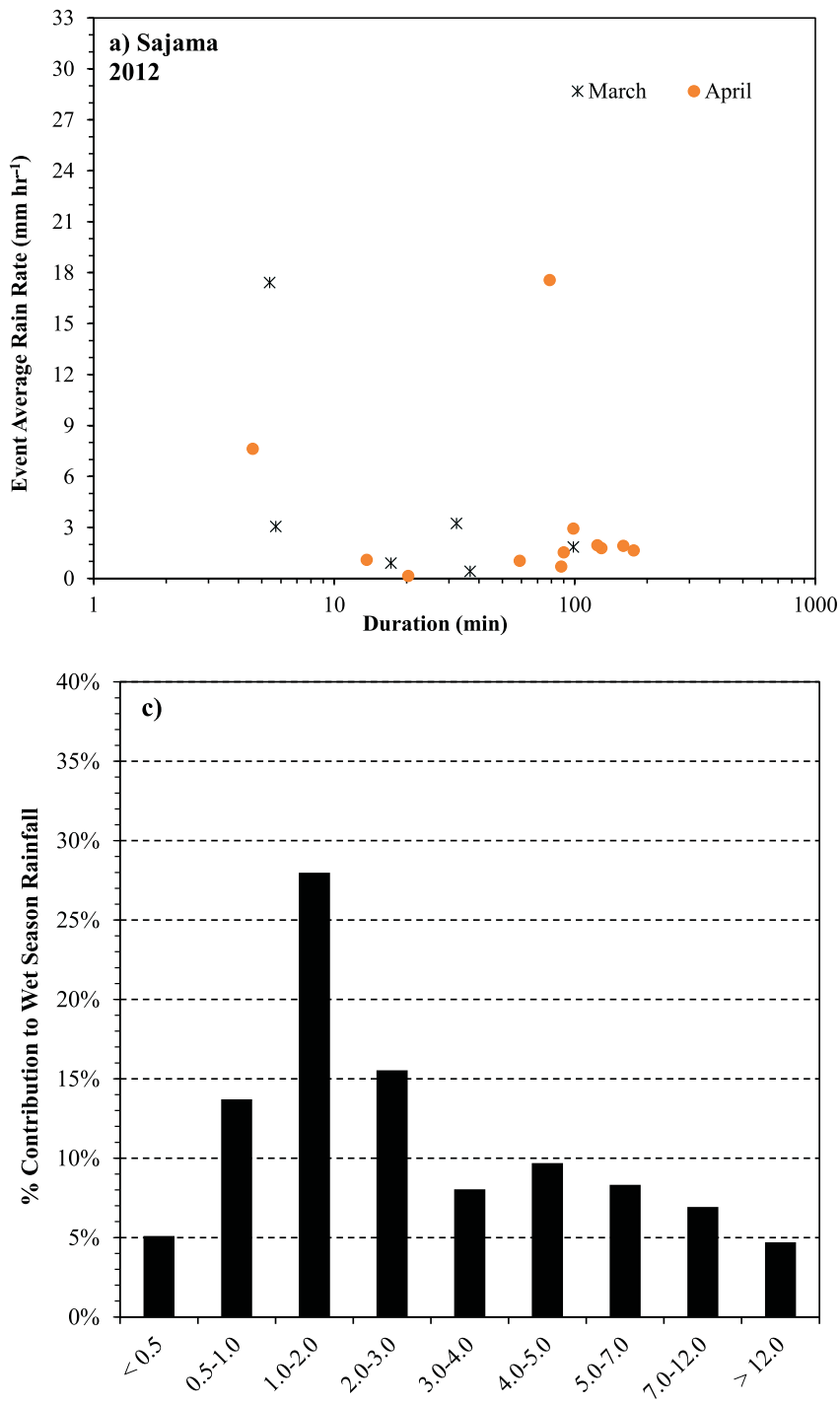

Event Average Rain Rate $\left(\mathrm{mm} \mathrm{hr}^{-1}\right)$ at Tuni

\section{Analysis of TRMM precipitation features}

\section{a. Mapping PFs by intensity}

In this section, we will discuss results from the entire TRMM data record and a selected wet season, 2003-04. For this wet season, the multivariate ENSO index, developed by Wolter and Timlin (2011) and posted on the web by the NOAA Earth System Research Laboratory, is $0.2-0.5$, within the neutral zone. During our 2011-12 field observation period, there were weak La Niña conditions $(-0.4$ to -0.9$)$, so we have opted to use the neutral hydrologic year October 2003-September 2004 to study PF geographic distribution and prestorm environmental conditions.

Tables 2 and 3 contain the results of cumulative distribution functions (CDFs) derived from PFs during the entire TRMM era for variables frequently used in the

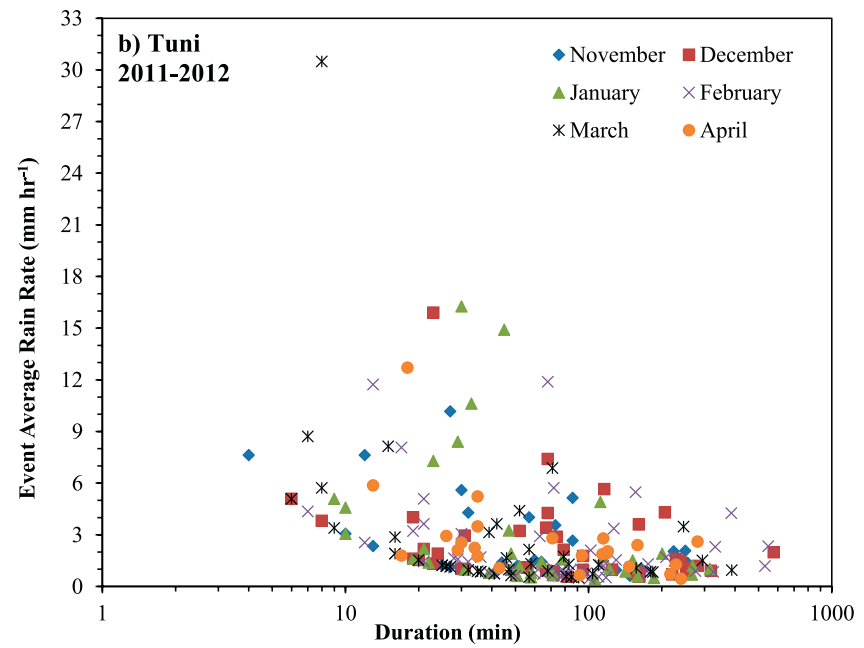

FIG. 5. Scatter diagrams (event average rain rate vs duration) for multitip events at (a) Sajama and (b) Tuni. Each month is indicated by a different shape and color marker. (c) Event average rain rates at Tuni vs contribution to November 2011-April 2012 total rainfall.

literature for comparisons of PF intensity (e.g., Liu et al. 2008). For MIN85, Table 2 provides results for the wet season (December-March) and dry season (AprilNovember) separately. The MIN85 wet season CDF is shifted right, toward lower values, particularly for the first to 10th percentiles, compared to the dry season CDF. Applying the nonparametric Mann-WhitneyWilcoxon rank-sum test to wet and dry season MIN85 PF samples for all years, the $p$ values were less than 0.01 , indicating that the wet and dry season PFs are different populations, with the wet season producing stronger PFs than the dry season.

The division of the panels in Fig. 6 is based on the wet season MIN85 CDF in Table 2, where the 10th percentile is $242 \mathrm{~K}$. The coldest $10 \%$ of PFs in Fig. 6a favor the highest elevations, with $40 \%$ of the PFs in Fig. 6 a occurring above $4000 \mathrm{~m}$ ( $10 \%$ of the study area) and 
TABLE 2. CDFs for selected percentiles of MIN85 and MINIR derived from PFs during the entire TRMM era. All units are in kelvin. MIN85 is listed for all months (second column), wet season PFs only (October-April, third column), and dry season PFs only (May-September, fourth column). MINIR (fifth column) is for all months.

\begin{tabular}{ccccc}
\hline \hline Percentiles & MIN85 all & Wet season & Dry season & MINIR \\
\hline 1 & 191 & 190 & 192 & 191 \\
2 & 209 & 207 & 213 & 198 \\
5 & 230 & 228 & 234 & 205 \\
10 & 244 & 242 & 247 & 213 \\
25 & 259 & 258 & 261 & 228 \\
50 & 268 & 268 & 269 & 249 \\
75 & 275 & 274 & 276 & 261 \\
\hline
\end{tabular}

$50 \%$ of PFs on eastern facing slopes (aspects between $20^{\circ}$ and $\left.160^{\circ}\right)$. Western facing PFs $\left(35 \%\right.$ between $200^{\circ}$ and $340^{\circ}$ ) are most visible along the west side of the Altiplano and along the west face of the Cordillera Occidental. Mesoscale convergence zones created by subsiding air along the front ranges may meet either turbulence from surface heating over the Altiplano or the equatorward advection of humid air along the west coast by extratropical troughs, thereby promoting the development of deep convection in these areas (e.g., Garreaud 2000; Garreaud et al. 2003; Seluchi et al. 2006). Figure $6 \mathrm{~b}$ depicts the distribution of the remaining $90 \%$ of PFs to illustrate two main points. First, there are considerably more symbols clustered along the eastern side and on the highest terrain in southern Peru. The cluster of symbols in southern Peru occurring around $14^{\circ}-15^{\circ} \mathrm{S}$ and $71^{\circ}-73^{\circ} \mathrm{W}$ can be compared to the local maxima in precipitation in the January (Fig. 2b) and annual (Fig. 3) climatologies. Second, weak PFs are distributed throughout Altiplano plains rather than preferentially near the front ranges as in Fig. 6a. It is possible that some of these PFs may have started their life cycle with stronger convection on the front range, weakening as they traversed the arid Altiplano plains. From our GISbased analysis of the topographic grid, we found a similar association between the frequency of weak PF occurrence and altitude and aspect, with $45 \%$ of weak PFs occurring on eastern facing slopes.

In the global census of deep convection, Liu et al. (2007) define deep convection as MINIR less than $210 \mathrm{~K}$. Globally, 35\% of the PFs from 1998 to 2004 have MINIR less than the $210-\mathrm{K}$ threshold, thus containing deep convection. In the central Andes, the 10th percentile for MINIR is $213 \mathrm{~K}$ (Table 2), slightly warmer than the deep convection threshold. Only $8 \%$ of the PFs in January 2004 had MINIR meeting the deep convection threshold, and their distribution was very similar to Fig. 6a, so Fig. 6 does not have a separate panel for MINIR. During the TRMM era, $96 \%$ of the PFs with MIN85 colder than $191 \mathrm{~K}$ also met the MINIR threshold for deep convection, decreasing to $60 \%$ for PFs with MIN85 colder than $230 \mathrm{~K}$ and to $36 \%$ for PFs with MIN85 colder than $244 \mathrm{~K}$. For the central Andes, even PFs in the second to 10th percentiles for MIN85 may not contain cold cloud tops indicative of deep convective cells.

Figure 7 provides additional visual perspective on the frequency and distribution of well-organized PFs with strong convection at the peak of the wet season. In January 2004 , only $4 \%$ of PFs had any lightning and only $8 \%$ had $40-\mathrm{dBZ}$ echo tops. Only $40 \%$ of the PFs with $40-\mathrm{dBZ}$ echo tops also produced lightning. In Fig. 7a, the PFs with $40-\mathrm{dB} Z$ echo tops are most likely to occur around the Altiplano or on the highest eastern-facing slopes. A plurality of the electrified PFs in Fig. 7b are in the southwestern side of the study area, the region most likely to be affected occasionally by mesoscale convergence zones set up by moist southwesterly transport from intruding extratropical troughs (e.g., Seluchi and Marengo 2000; Seluchi et al. 2006).

The CDFs in Table 3, based on observations from the PR and LIS for the entire TRMM era, are for variables are related to system structure, namely the height of the column of light rain (MAXHT20), the presence of strong convection (LFR and MAXHT40), and height of the column of heavy rain (MAXHT40). Extrapolating from

TABLE 3. CDFs for selected percentiles of MAXHT20, MAXHT40, and LFR derived from PFs during the entire TRMM era. Echo heights (columns 2 and 3) are in kilometers above mean sea level, and LFR (columns 4 and 5) is in flashes per minute. Column 4 is based on a screen of the PFs to match the global lightning study of Liu et al. (2012), and column 5 is based on the entire PF size spectrum.

\begin{tabular}{ccccc}
\hline \hline Percentiles & MAXHT20 $(\mathrm{km})$ & MAXHT40 $(\mathrm{km})$ & LFR (flashes $\left.\min ^{-1}\right)$ NPR $\geq 8$ & LFR (flashes min $^{-1}$ ) All \\
\hline 99 & 13.50 & 7.25 & 8.25 & 2.50 \\
98 & 12.50 & 6.00 & 5.00 & 1.25 \\
95 & 10.50 & 4.25 & 2.00 & 0.00 \\
90 & 9.00 & 0.00 & 0.00 & 0.00 \\
75 & 7.50 & 0.00 & 0.00 & 0.00 \\
50 & 6.25 & 0.00 & 0.00 & 0.00 \\
25 & 5.00 & 0.00 & 0.00 & 0.00 \\
\hline
\end{tabular}



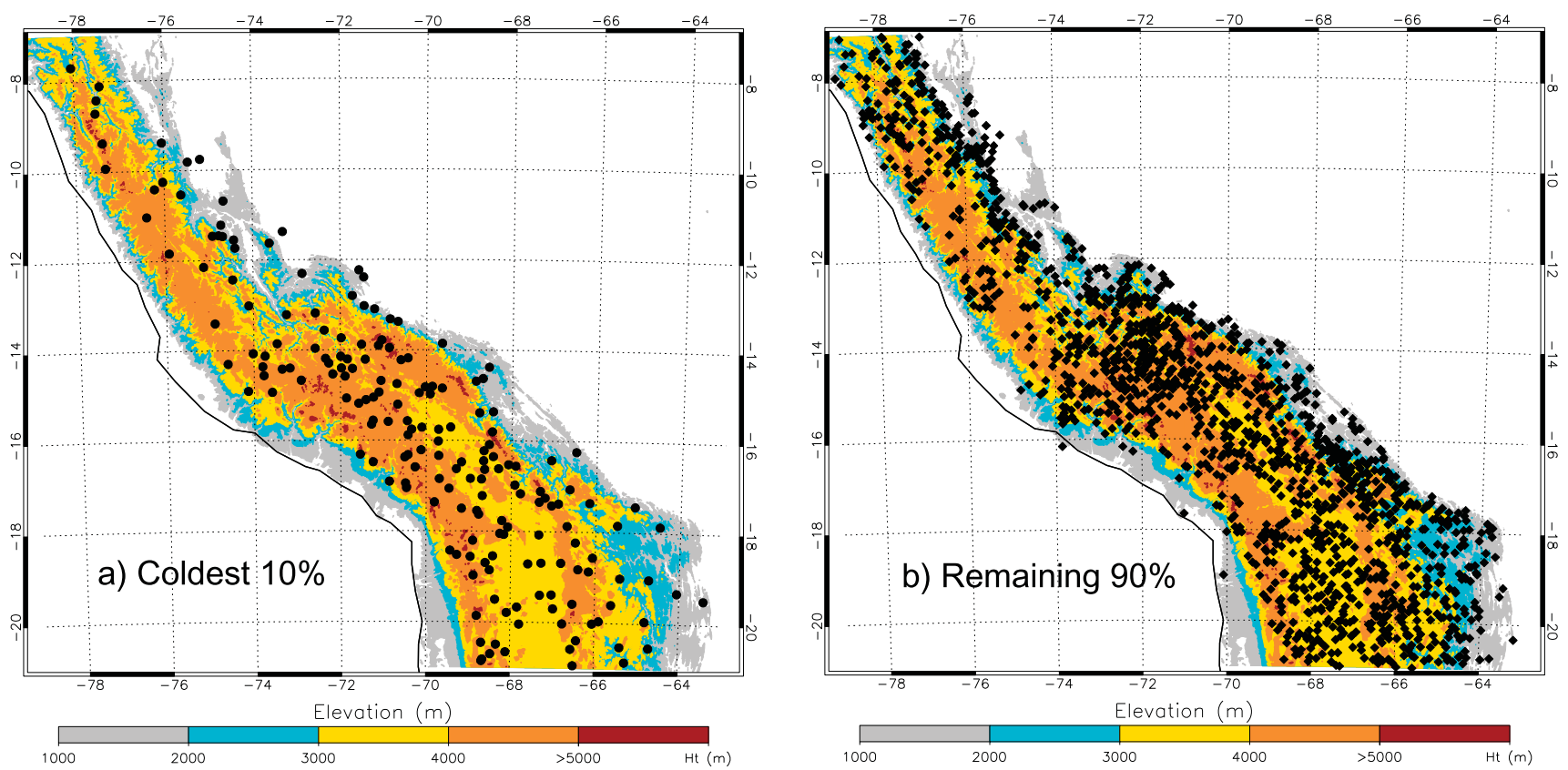

FIG. 6. (a) A map of the coldest 10\% (MIN85 < 243 K) PFs in January 2004, plotted as black circles on the elevation contours. (b) A map of the remaining $90 \%$ of PFs in January 2004, plotted as black diamonds.

Table 3, fewer than 7\% of PFs had 20-dBZ echo tops greater than $10 \mathrm{~km}$, and fewer than $6 \%$ had $40-\mathrm{dBZ}$ echo tops greater than $1 \mathrm{~km}$. Globally, $11.5 \%$ of PFs over land are electrified, with $1.8 \%$ of land PFs having flash rates greater than 10 flashes $\min ^{-1}$ (Liu et al. 2012). In Table 3, column 3 shows the CDF for PFs screened (NPR $\geq 8$ ) according to Liu et al. (2012), and column 4 shows the $\mathrm{CDF}$ for all PFs for comparison. About $9 \%$ of the
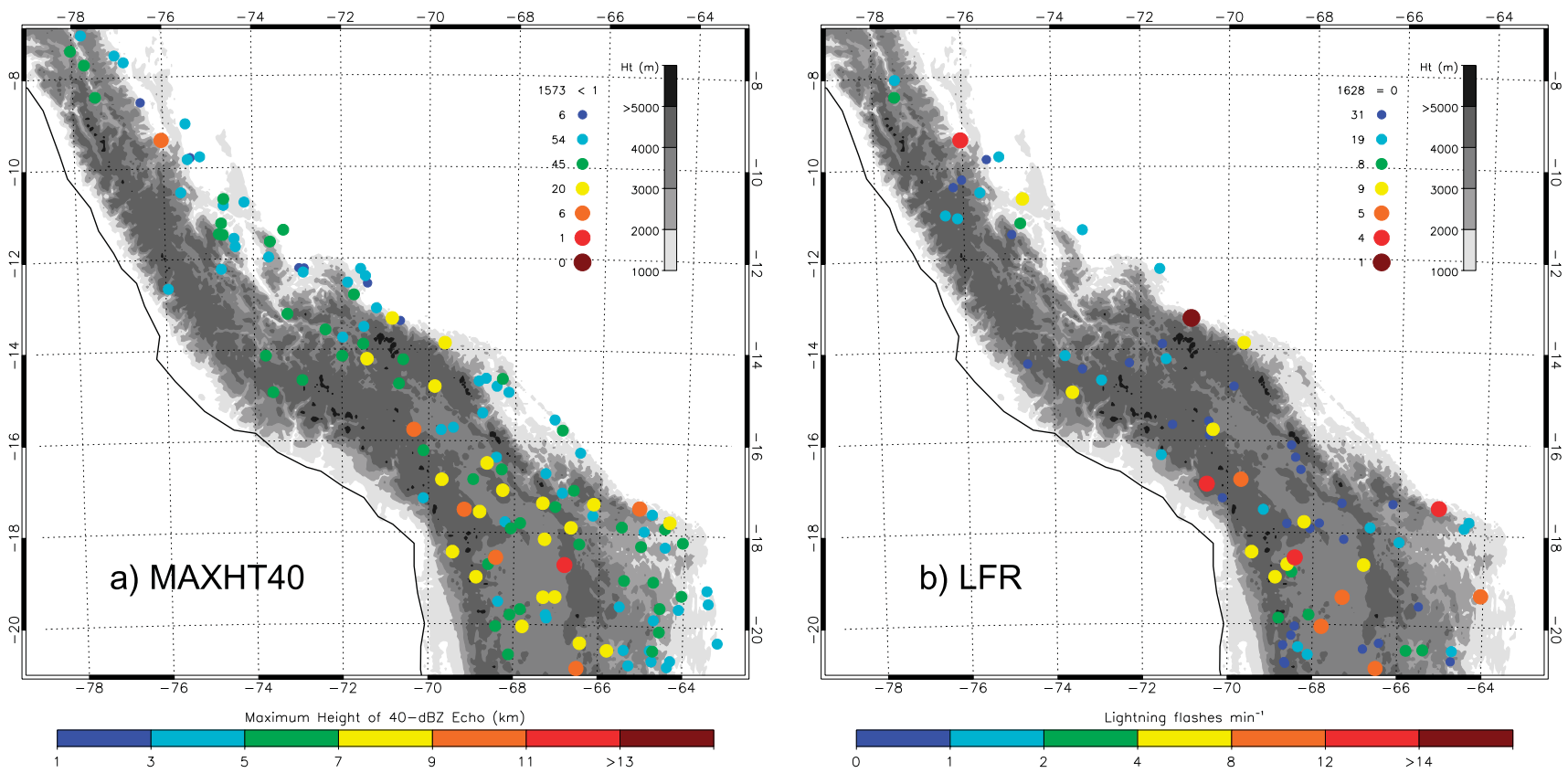

FIG. 7. Maps of January 2004 PFs for (a) MAXHT40 (km) and (b) LFR (flashes $\min ^{-1}$ ). PFs with nonzero MAXHT40 or LFR are plotted as filled circles. The cool to warm colors in the bottom legend and the increasing symbol sizes indicate lower to higher echo-top heights or flash counts. The legends in the top right corner are the PFs in each height or flash count class (left) and the elevation contours (right). The PF legend includes the number of PFs with no detectable value for MAXHT40 or LFR. To maximize the contrast with the PFs, the elevation contours are in gray shades. The elevation contour levels are the same as Fig. 1. 
screened PFs in column 3 ( $<5 \%$ of all PFs) are electrified, and less than $1 \%$ of the screened PFs have flash rates greater than 10 flashes $\min ^{-1}$. Even the larger, better organized PFs in the central Andes are less likely to be electrified than the global land average.

\section{b. Regional comparisons of PF intensity}

Starting in this subsection, we show results from three other regions to compare to the central Andes: the Himalayas $\left(24^{\circ}-40^{\circ} \mathrm{N}, 60^{\circ}-100^{\circ} \mathrm{E}\right.$; May-September $)$, the semiarid zone of West Africa $\left(10^{\circ}-25^{\circ} \mathrm{N}, 20^{\circ} \mathrm{W}-32^{\circ} \mathrm{E}\right.$; May-September), and the Amazon basin $\left(0^{\circ}-15^{\circ} \mathrm{S}, 75^{\circ}-\right.$ $50^{\circ} \mathrm{W}$; January-May and September-December). These regions are depicted because of similarities in climate (Himalayas and semiarid West Africa), elevation (Himalayas), or dynamical links (Amazon). For consistency with the central Andes, the Himalayas PF sample contains only PFs occurring above $1000 \mathrm{~m}$ to screen out the effect of low-level monsoon moisture transport. In the global maps of PF size and intensity in the previous study by Liu et al. (2008), the highlands of the central Andes and Himalayas have lower percentages of PFs over $2000 \mathrm{~km}^{2}$ and MIN 85 below $250 \mathrm{~K}$ than the Amazon and West Africa.

Figure 8 further defines the intensity differences mapped at a larger scale in Liu et al. (2008). Figure 8a contains CDFs over the entire range of MIN85, and Fig. $8 b$ focuses on the top of the CDFs. In Fig. 8a, the central Andes and Himalayas CDFs are clearly separate from the Amazon and West African CDFs with a greater share of the central Andes and Himalayas PF populations at the warmer end of the distribution $(>240 \mathrm{~K})$. The greater likelihood of weak convection in the central Andes CDF is comparable to the field data in Fig. 5c. In Fig. 8b, West Africa and Amazon have a larger share of their PF populations at brightness temperatures unambiguously associated with deep convection $(>200 \mathrm{~K})$. West Africa's 10th percentile is $15 \mathrm{~K}$ colder than the Amazon and the central Andes, but its first percentile is 40 and $80 \mathrm{~K}$ colder, respectively. The results of Mann-Whitney-Wilcoxon tests conducted on each pair of regions in Fig. 8 reveal that there are four distinctly different PF populations $(p$ values $<0.01$ ). Figure $8 \mathrm{~b}$ reveals the subtle separation in the CDFs between the Himalayas and the central Andes that, despite similar slopes, triggered a significant result. Well-organized PFs with strong to intense deep convection are least likely to occur in the central Andes, slightly more likely in the Himalayas, and much more likely in West Africa and the Amazon.

\section{c. Regional comparisons of PF size}

Table 4 contains wet season CDFs for size, given as the number of PR pixels (NPR), for the central Andes and the other comparison regions. More than $75 \%$ of central Andes PFs are less than the 8-pixel screen $\left(200 \mathrm{~km}^{2}\right)$ proposed in Liu et al. (2008). Figure 9 is a map of the January 2004 PFs in the largest $10 \%$ of NPR (i.e., greater than $20 \mathrm{PR}$ pixels, approximately $500 \mathrm{~km}^{2}$ ). The geographic distribution of PFs in Fig. 9 is similar to Fig. $6 \mathrm{a}$ in which the larger PFs occur more frequently over the higher elevations and in the places where mesoscale convergence zones are likely to form. Over the TRMM era, the $10 \%$ largest PFs have a large overlap with the $10 \%$ coldest PFs. The annual average overlap of PFs classified as both intense and large is $80 \%$ annually, varying up to $\pm 10 \%$ by month, lower during dry season months.

Because the CDFs for PF size span several orders of magnitude, we found that a table rather than a graph more effectively displayed the subtle but significant ( $p$ values $<0.01$ ), differences among the four regions in Table 4. In Table 4, the percentile values for the Amazon and West Africa are 2-3 times larger than for the central Andes and the Himalayas. That is, large PFs are more common in the Amazon and West Africa and are more likely to be larger than the large PFs in the central Andes and the Himalayas. As in Fig. 8, it appears that the central Andes and the Himalayas have very similar populations, but hypothesis testing revealed that these samples belong to different populations, with PFs over 20 PR pixels more common in the Himalayas compared to the central Andes. The size results are similar to the intensity results. The Amazon and West Africa are more likely to have larger as well as better organized PFs than the mountainous regions, and development of large, well-organized PFs is more likely in the Himalayas than in the central Andes.

\section{d. Contributions to annual rainfall by climate class}

Global (Nesbitt et al. 2006; Yang and Smith 2008; Liu and Zipser 2009; Liu 2011) and regional studies (e.g., Petersen et al. 2002; Mohr 2004; Hirose and Nakamura 2005; Nesbitt and Anders 2009; Xu 2013) of rainfall contributions with respect to PF characteristics have emphasized the importance of the largest and most intense PFs to regional rainfall statistics. In the central Andes, the largest $2 \%$ of PFs contribute $43 \%$ of the annual rainfall and the coldest $2 \%$ of PFs contribute $34 \%$ of the rainfall. The PFs in the largest and coldest $2 \%$ in the central Andes tend to be significantly smaller and weaker than comparable regions, and these contributions, while important, are also lower than the largest and coldest $2 \%$ in other areas of the tropics such as the tropical oceans (50\%; Liu and Zipser 2009) or West Africa (60\%-70\%; Mohr 2004). Many of the PFs important to the central Andes would be screened out as too small to make a noteworthy contribution to regional 

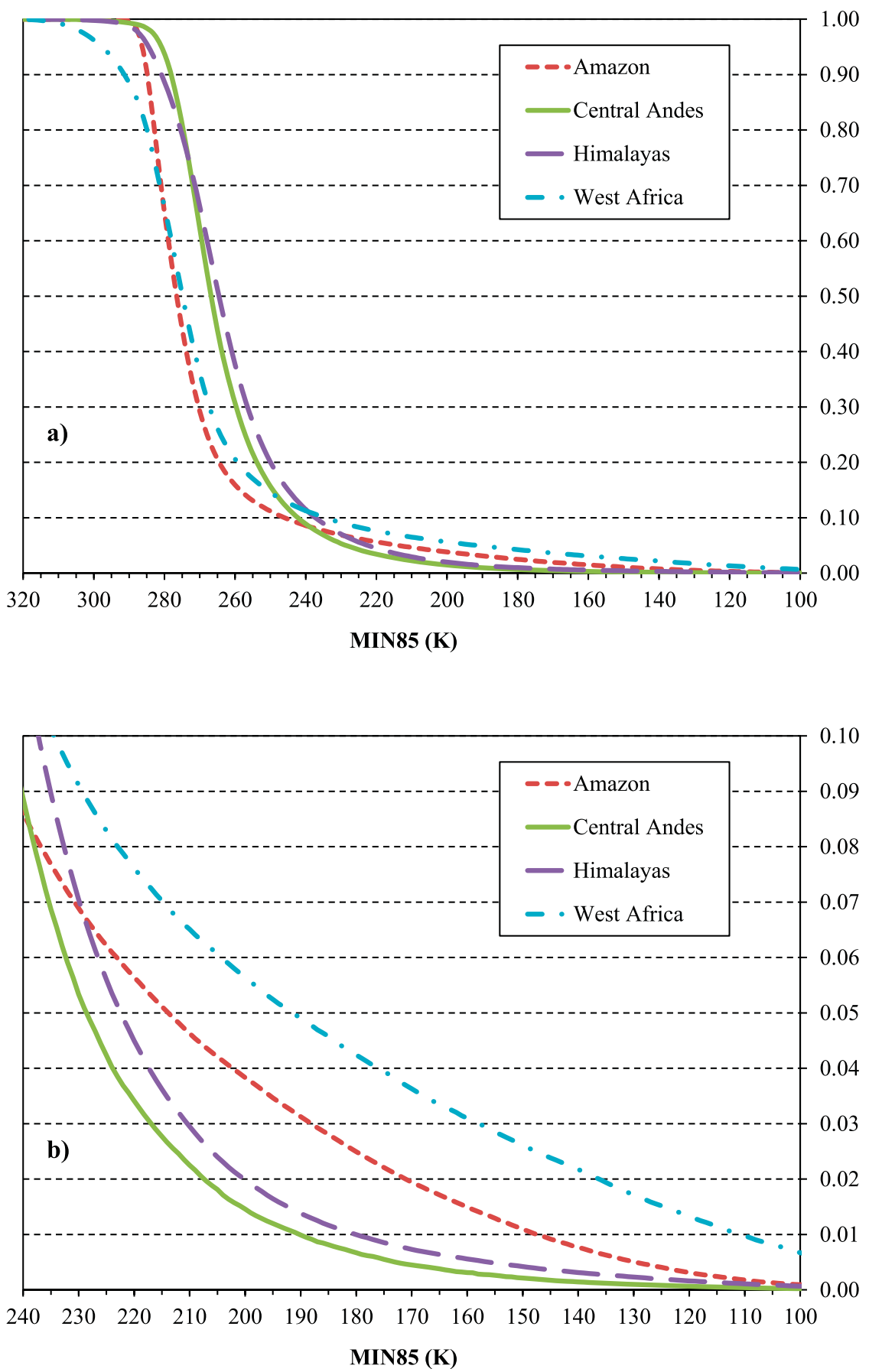

FIG. 8. Wet season CDFs for MIN85 (K) for the central Andes (green, solid line; October-April) and comparison regions Amazon (red, short dashes; January-May and September-December), Himalayas (purple, long dashes; May-September), and West Africa (blue, dash-dotted; MaySeptember) for the ranges (a) $320-100 \mathrm{~K}$ and (b) $240-100 \mathrm{~K}$. Note that (b) is the upper portion of the MIN85 CDFs to focus on the PFs that are most likely to have deep convection.

rainfall (cf. Liu et al. 2008). Because the traditional metrics such as MIN85, MINIR, and MAXHT40 suggest that well-organized convective systems with deep convection are less than $10 \%$ of the PF population in the central Andes, we chose to display contributions to rainfall totals with respect to a rain rate intensity spectrum rather than the traditional metrics. In Fig. 10, a bar chart depicts the contributions to annual rainfall for the TRMM era from the PR. Confidence in the accumulated rainfall statistics is linked to confidence in the PR rainfall retrieval algorithms. The global and regional PF rainfall studies cited earlier demonstrate 
TABLE 4. Wet season CDFs for selected percentiles of NPR for the central Andes (second column) and comparison regions. All units are PR-pixels per PF. The last row lists the percentage of the regional sample composed of PFs with only one PR pixel. The conversion to area units is NPR $\times 25 \mathrm{~km}^{2}$.

\begin{tabular}{ccccc}
\hline \hline & $\begin{array}{c}\text { Central } \\
\text { Andes }\end{array}$ & Himalayas & $\begin{array}{c}\text { West } \\
\text { Africa }\end{array}$ & Amazon \\
\hline 99 & 175 & 200 & 725 & 525 \\
98 & 95 & 100 & 325 & 225 \\
95 & 44 & 46 & 95 & 80 \\
90 & 20 & 22 & 38 & 36 \\
75 & 7 & 7 & 11 & 11 \\
50 & 2 & 2 & 4 & 4 \\
$\%$ of PFs $=1$ & 39 & 40 & 29 & 25 \\
PR pixel & & & & \\
\hline
\end{tabular}

a strong correlation between accumulated rainfall from well-organized, long-lived events and their volumetric rainfall. For the short duration events in the study region, a relevant study is Amitai et al. (2012), in which instantaneous rain rate estimates from the PR compare very well with contemporaneous 1-min rain rates in the recording gauge network of the arid Walnut Gulch,
Arizona, watershed. Hence, rainfall from weak PFs in the study region would be well characterized by instantaneous PR rain rate estimates particularly for the short duration events that are the majority of the events at the recording rain gauge sites (Fig. 5).

To understand regional variability, the PF contributions to annual rainfall in Fig. 10 are stratified by three classes determined from the 3B43 climatology mapped in Fig. 3. The blue bars in Fig. 10 correspond to the western side (gray to blue) of Fig. 3 , the green bars to the central-east region (green to orange), and the red bars to the eastern facing front ranges (red to brown). There is a $20 \%-25 \%$ contribution for at least one series for rain rates $1.0-4.0 \mathrm{~mm} \mathrm{~h}^{-1}$ with negligible contributions in the lowest and two highest bins. There is a clear shift in the distributions to higher values from the arid class (blue bars; $64 \%$ of study region) to the humid class (red bars; $9 \%$ of study region). The majority of the rainfall in the intermediate (green bars; $27 \%$ of study region) and arid classes is $1-3 \mathrm{~mm} \mathrm{~h}^{-1}$. However, the intermediate class has a broader distribution with greater contributions over $5 \mathrm{~mm} \mathrm{~h}^{-1}$, and the arid class is the only class with

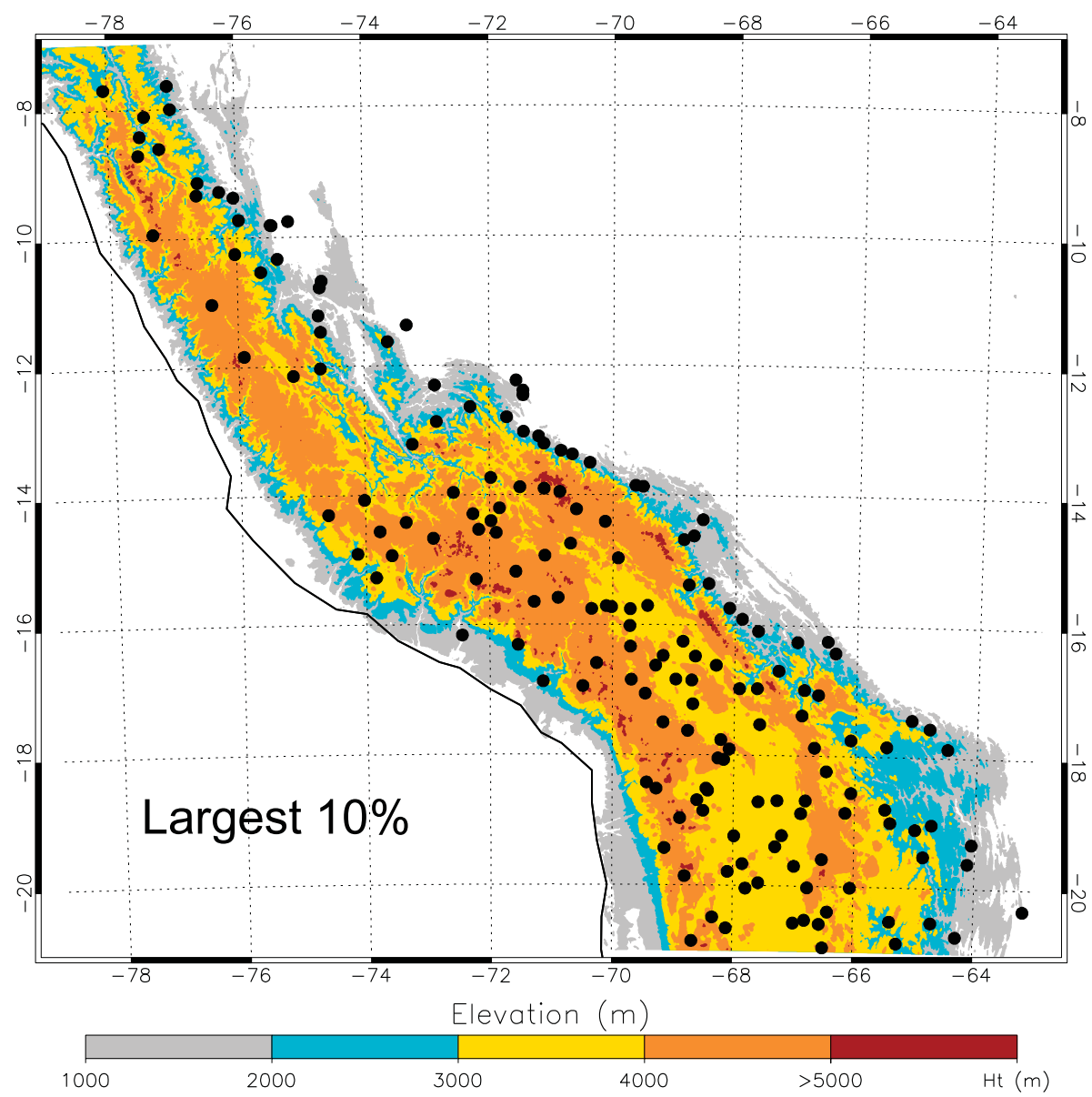

FIG. 9. A map of the January 2004 PFs (black circles) in the largest $10 \%$ of NPR, that is, PFs greater than $20 \mathrm{PR}$ pixels $\left(500 \mathrm{~km}^{2}\right)$. 


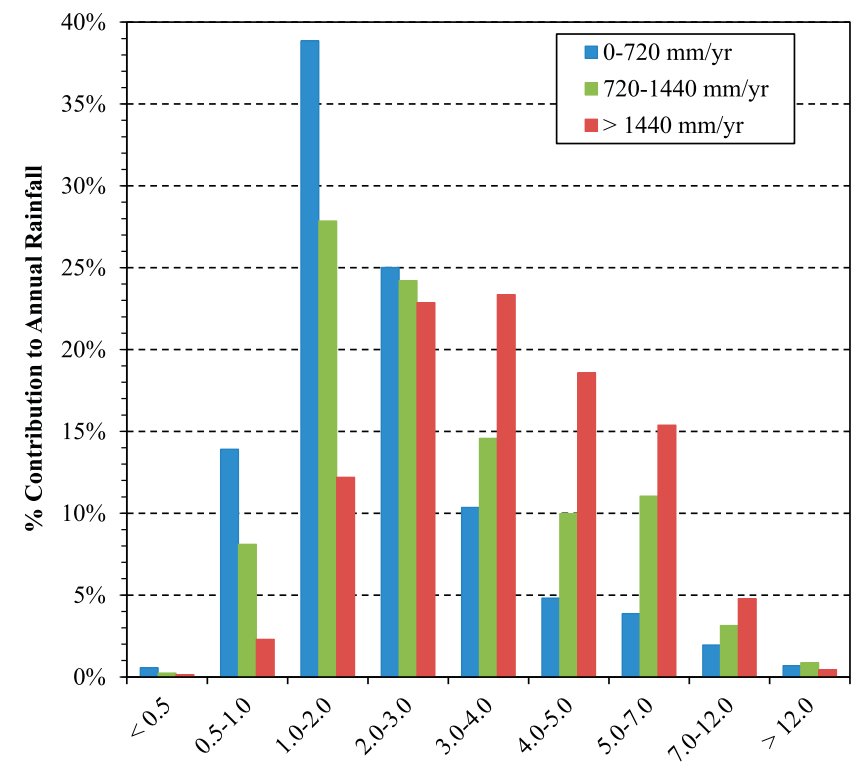

PF Area-Average Rain Rate $\left(\mathrm{mm} \mathrm{hr}^{-1}\right)$

FIG. 10. PF area-average rain rates vs contribution to annual rainfall during the TRMM era. Area-average rain rates $\left(\mathrm{mm} \mathrm{h}^{-1}\right)$ were derived by dividing volumetric rain rates $\left(\mathrm{km}^{2} \mathrm{~mm} \mathrm{~h}^{-1}\right)$ by the number of PR pixels and by $25 \mathrm{~km}^{2}$ pixel $^{-1}$. The PFs were stratified by the 3B43 climatology (Fig. 3). The blue bars (left) are for PFs in areas with less than $720 \mathrm{~mm} \mathrm{yr}^{-1}$ (arid class), the green bars (center) for PFs at $720-1440 \mathrm{~mm} \mathrm{yr}^{-1}$ (intermediate class), and the red bars (right) for PFs at greater than $1440 \mathrm{~mm} \mathrm{yr}^{-1}$ (humid class).

a noteworthy contribution from the $0.5-1.0 \mathrm{~mm} \mathrm{~h}^{-1}$ bin. The humid class peaks at the $3.0-4.0 \mathrm{~mm} \mathrm{~h}^{-1}$ bin with substantial contributions up to the $5.0-7.0 \mathrm{~mm} \mathrm{~h}^{-1}$ bin.

The rain rate intensity spectra from Tuni (Fig. 5) and from the PR (Fig. 10) reinforce the impression that the majority of the seasonal rainfall throughout the central Andes is contributed by events with rain rates less than $4.0 \mathrm{~mm} \mathrm{~h}^{-1}$. Light-moderate rainfall, $3-7 \mathrm{~mm} \mathrm{~h}^{-1}$, is more important in the humid class $(9 \%$ of the study region) than in the more arid regions west of it. Although rain rates greater than $7 \mathrm{~mm} \mathrm{~h}^{-1}$ from stronger, better organized PFs do occur, particularly in the humid zone, there are not enough PFs capable of these rain rates in any of the climate zones for their contribution to be more than minimal.

Regional variability in the diurnal cycle has been linked to differences in system size and convective-stratiform separation (Yang and Smith 2008; Romatschke and Houze 2011; Biasutti et al. 2012; Romatschke and Houze 2013). Perry et al. (2014) show that Cuzco, in the humid east (Fig. 1), has a bimodal diurnal cycle with a smaller peak in the afternoon and a larger peak around midnight. In Fig. 4b, the peak of Tuni's unimodal diurnal cycle is in the late afternoon, with little contribution during the late night to early morning hours. Figure 11a contains the diurnal cycles constructed from the PF database. The bimodal diurnal cycle for the humid class (red line with triangles) in Fig. 11a is similar to Perry et al. (2014) and different from the rest of the study region. As in Tuni, the arid (blue line with circles) and intermediate (green line with squares) classes are unimodal, peaking in the late afternoon with decreasing contributions throughout the evening to early morning. Compared to the arid class, the intermediate class has a lower afternoon peak and more rainfall in the evening to morning hours.

To complement Fig. 11a, Fig. 11b contains the spectra of convective-stratiform separation. In Fig. 11b, the majority of the rainfall in all classes is contributed by stratiform structure. The upward curve at 1.0 reflects the modest contribution from isolated cumulonimbus. From the arid class to the humid class, the contribution from convective structure increases. By the convective pixel to total NPR ratio of 0.3 , the cumulative total rainfall is $72 \%$ for the arid class, $68 \%$ for the intermediate class, and $60 \%$ for the humid class. Table 5 summarizes the differences for the median and 90th percentile for NPR and the percentages of convective and stratiform structure for each of the three classes. The arid class sample consists of many very small PFs and some large PFs around the Altiplano and along the southwest coast (Figs. 7 and 9) that shift the upper portion of its CDF to the right of the intermediate class CDF. Small PFs with decayed convection/stratiform structure dominate the totals in the bottom rows of Table 5. Along the eastern front range, the humid class PFs tend to be larger than in the other two classes, with a larger share of convective structure, suggesting better system organization.

From Figs. 4 and 5, it is reasonable to infer that there are too few afternoon events at Tuni and Sajama well organized enough to persist into the evening hours to make a significant contribution as a class to annual rainfall. The results in Fig. 11 and Table 5 suggest that this inference is more widely applicable. Both the arid and intermediate classes have diurnal cycles, suggesting that afternoon convection triggered by local topography typically does not evolve into larger PFs, namely, nocturnal MCSs with deep convective cores and broad stratiform regions, a process described by Romatschke and Houze (2010). Even if the topography can produce strong katabatic outflows, limited moisture availability would preclude further development after the initial CAPE was consumed (Egger et al. 2005; Bendix et al. 2006; Bendix et al. 2009). The process of evolution into better organized PFs with stronger convection and broader stratiform regions occurs often enough in the humid zone above $1000 \mathrm{~m}$ to result in a bimodal diurnal cycle and a rain rate histogram shifted to the right. Compared to the PFs occurring in the foothills of the Andes in 

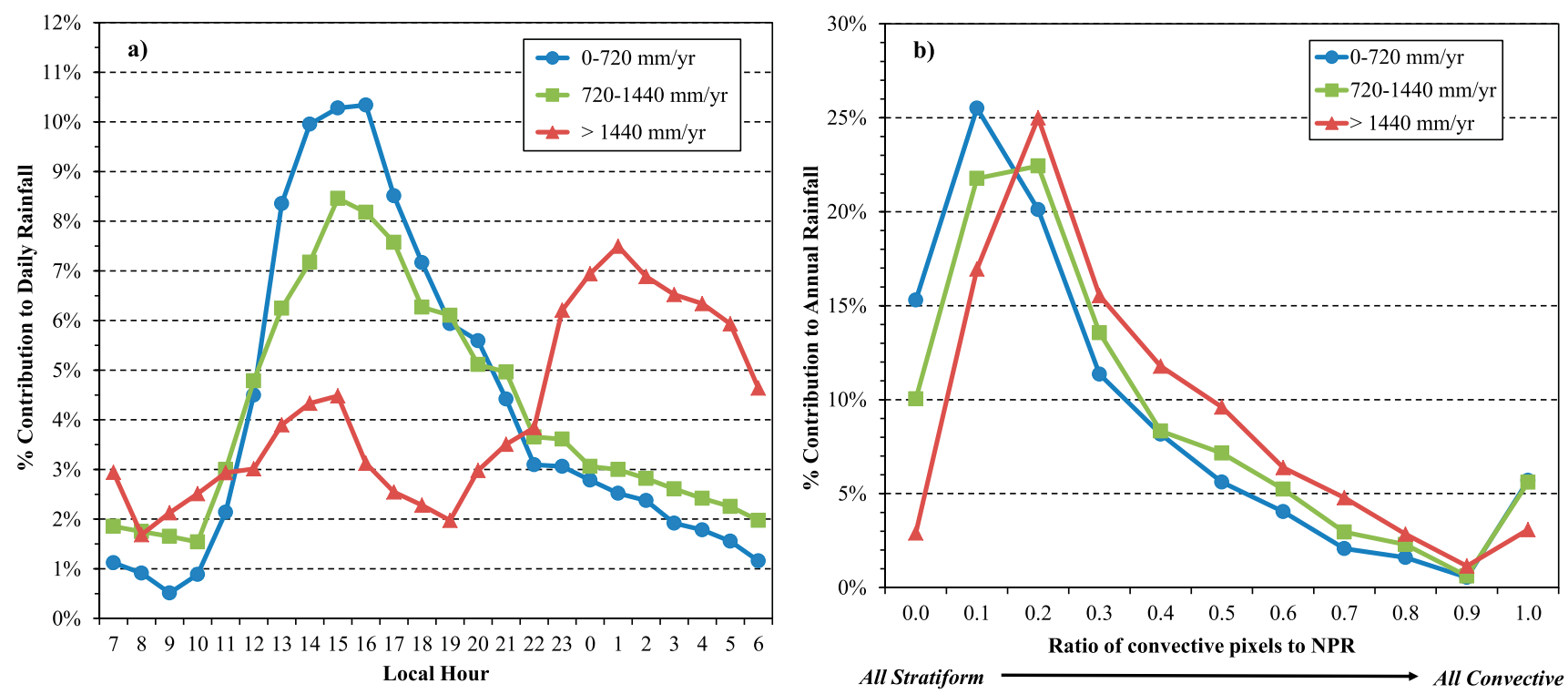

FIG. 11. (a) The diurnal cycle determined from the PF volumetric rain rates from the PR. (b) The contribution to annual rainfall with respect to the ratio of convective pixels to NPR. A ratio of 0 is a PF with only stratiform structure, and 1 is a PF with only convective structure. In both panels, the stratification by the 3B43 climatology is the same as Fig. 10. Blue lines with circles are the arid class $(0-$ $\left.720 \mathrm{~mm} \mathrm{yr}^{-1}\right)$. The green lines with squares are the intermediate class $\left(720-1440 \mathrm{~mm} \mathrm{yr}^{-1}\right)$. The red lines with triangles are the humid class $\left(>1440 \mathrm{~mm} \mathrm{yr}^{-1}\right)$.

Romatschke and Houze (2010, 2013) and of the Himalayas in Romatschke and Houze (2011), the humid class PFs in our study are weaker and less organized than in these studies, where lower-elevation PFs benefit from the maximum moisture transport by the SALLJ and the Indian monsoon, respectively.

\section{Discussion of the prestorm environment}

\section{a. Analysis of the environmental instability}

Because of the complex terrain of our study region, we used the high-resolution $\left(0.5^{\circ}\right)$, next-generation CFSR reanalysis dataset from NCEP for the prestorm environmental analysis of PFs in the representative hydrologic year 2003/04. Figure 12 contains wet season CDFs for pseudoadiabatic CAPE (left panel) and precipitable water (PW) (right panel) for the three climate classes and West Africa for comparison. In Fig. 12a, the 50th percentile for all three classes is around $30 \mathrm{~J} \mathrm{~kg}^{-1}$. The curves of the CDFs for the arid and intermediate classes versus the humid class diverge at the 75 th percentile such that the 90th percentiles are $550 \mathrm{~J} \mathrm{~kg}^{-1}$ for the arid and intermediate classes and $750 \mathrm{~J} \mathrm{~kg}^{-1}$ for the humid class. For the dry season (not shown), the 50th percentile for all classes is $0 \mathrm{~J} \mathrm{~kg}^{-1}$ and the 90th percentiles are $70 \%-75 \%$ lower than for the wet season. While there is no significant separation between the arid and intermediate class CDFs for CAPE, for PW (Fig. 12b) the gap is $1-8 \mathrm{~mm}$ between the arid and intermediate classes. There is a larger gap between the intermediate and humid classes of $8-15 \mathrm{~mm}$. The 50th and 90th percentiles for the intermediate class, 15 and $28 \mathrm{~mm}$, are $50 \%$ and $35 \%$ lower, respectively, than for the humid class. In the dry season (not shown), the 50th and 90th percentiles for all classes are $20 \%$ and $15 \%$ lower than the wet season percentiles.

TABLE 5. Selected size (NPR) percentiles and structure type, stratified by the 3B43 climatology. Rows 3 and 4 are the percentiles for NPR; rows 6 and 7 are the percentages of pixels classified by type (convective or stratiform) for all PFs in the TRMM era.

\begin{tabular}{|c|c|c|c|}
\hline & Arid $0-720 \mathrm{~mm} \mathrm{yr}^{-1}$ & Intermediate $720-1440 \mathrm{~mm} \mathrm{yr}^{-1}$ & Humid $>1440 \mathrm{~mm} \mathrm{yr}^{-1}$ \\
\hline \multicolumn{4}{|c|}{ NPR percentiles } \\
\hline 50 & 3 & 2 & 3 \\
\hline 90 & 18 & 15 & 22 \\
\hline \multicolumn{4}{|c|}{ Percentage of pixels classified as } \\
\hline Convective & 16 & 20 & 25 \\
\hline Stratiform & 84 & 80 & 75 \\
\hline
\end{tabular}



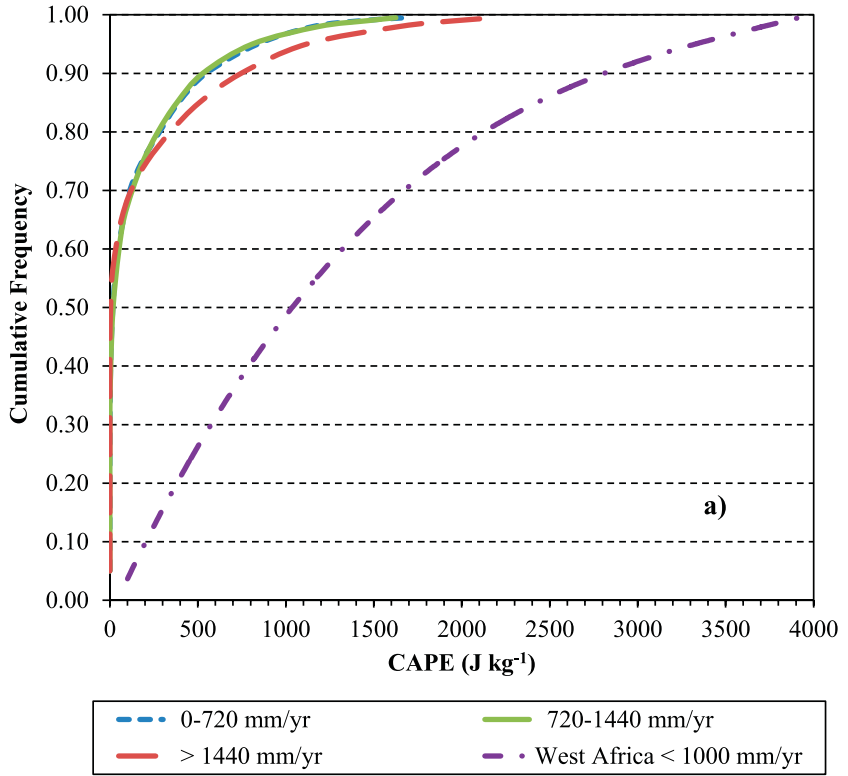

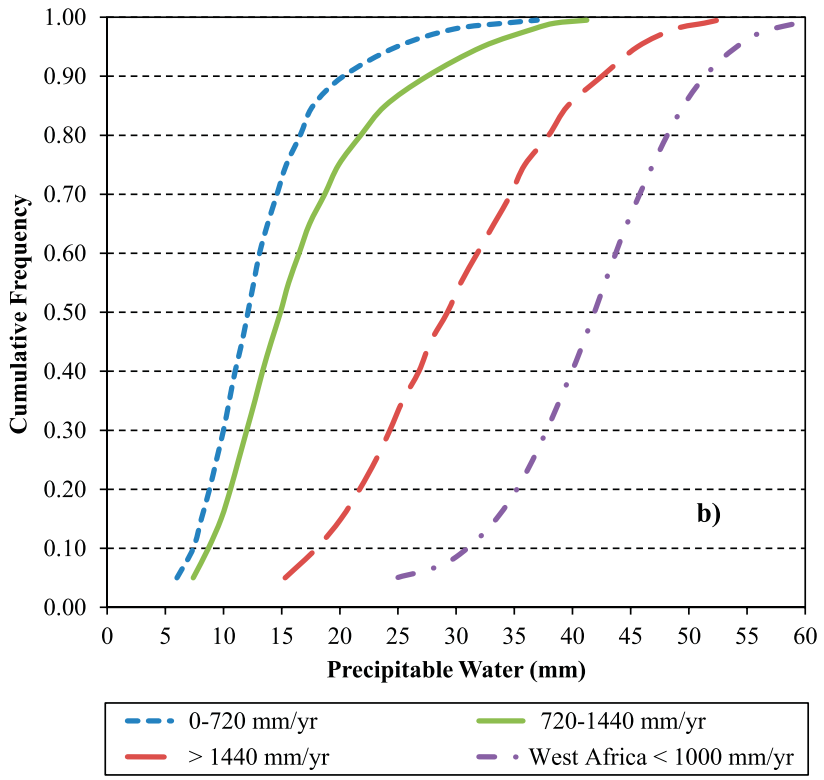

FIG. 12. Wet season CDFs for (a) CAPE $\left(\mathrm{J} \mathrm{kg}^{-1}\right)$ and (b) PW (mm) for PFs stratified by 3B43 climatology and for comparison region West Africa (purple dash-dotted lines). The blue short dashed lines are for arid class PFs $\left(<720 \mathrm{~mm} \mathrm{yr}^{-1}\right)$, the green solid lines for intermediate class PFs (720-1440 $\mathrm{mm} \mathrm{yr}^{-1}$ ), and the red long dashed lines for humid class PFs $\left(>1440 \mathrm{~mm} \mathrm{yr}^{-1}\right)$.

In comparison, the CDFs for West African PFs are shifted far to the right of the humid class in both panels of Fig. 12. The median CAPE and PW in West Africa are $1000 \mathrm{~J} \mathrm{~kg}^{-1}$ and $40 \mathrm{~mm}$, respectively. In sensitivity studies of intense organized convection in both the midlatitudes and tropics, $35 \mathrm{~mm}$ is considered a dry or low-instability initial sounding (McCaul et al. 2005; Takemi 2007). Although weak PFs are majority of the population in West Africa as they are in the central Andes, the upper portions of the West African CAPE CDF (Fig. 12a) and intensity CDF (Fig. 8b) result from the high instabilities and thus intense convection that can occur in an environment that has a combination of high surface heating and an active monsoon. Analogous to the central Andes, the arid high plateau of East Asia has a median summer PW of less than $20 \mathrm{~mm}$ and a median CAPE around $500 \mathrm{~J} \mathrm{~kg}^{-1}$ from $2.5^{\circ}$ NCEP reanalysis, resulting in PFs that tend to be smaller and weaker than humid regions to the east and south $(\mathrm{Xu}$ 2013).

\section{b. Synthesis of results}

In Fig. 4a, Tuni and Sajama have almost the same number of days of rainfall, typically composed of multiple short duration afternoon events when surface differential heating and katabatic outflow from the high peaks are strongest. There are usually more events per day at Tuni, spread out over a longer period in the afternoon. In Fig. 5, Tuni has more events over $60 \mathrm{~min}$, and the rainfall rates tend to be slightly higher. The results from the PF database in Figs. 10-12 for the arid and intermediate classes are consistent with our field data. The humid class diurnal cycle (Fig. 12b), highlighting the importance of nocturnal long-duration events, is consistent with the observations in Perry et al. (2014). There is a general depiction from the field and remote sensing data of most central Andes PFs as small, weak, and shallow convective systems composed primarily of decayed convective/stratiform structure. It is these weak events $\left(0.5-4 \mathrm{~mm} \mathrm{~h}^{-1}\right)$ that contribute the majority of seasonal rainfall at our field sites and to the region in general across all climate zones.

From the reanalysis, most of the PFs in the study region develop in a low humidity/low instability environment that makes significant system development unlikely. Proximity to the large-scale easterly moisture transport and the east-to-west rainout govern the nature of the central Andes CDFs in Fig. 12. In the Tuni and Sajama data, there were rain rates suggesting a few deep convective cells, but they did not organize into longer-lasting convective systems. There were a few convective systems that lasted several hours but never developed strong convection and rarely persisted after sunset. The probability of a prestorm environment more conducive to the development of well-organized PFs (i.e., PW greater than $35 \mathrm{~mm}$ and/or CAPE greater than $500 \mathrm{~J} \mathrm{~kg}^{-1}$ ) is highest along the eastern front range, decreasing toward the west. Development of a high instability environment in the highlands of the central Andes and the Himalayas is much less common and tends to be less extreme than in 
West Africa, the Amazon, and other areas such as the eastern foothills where substantial low-level moisture transport is available. Although there are well-organized PFs with high pre-environment CAPE that occurred on the eastern front range, around the Altiplano, and in the southwest (Figs. 7 and 9), they were too few to shift the CDFs appreciably. The more frequent occurrence of well-organized PFs in areas where mesoscale convergence zones may occur points to the importance of having this scale of forcing, an enhanced moisture flux convergence, in a region where the low-level environment tends to be dry and stable.

\section{Summary}

In this paper, we used both surface- and space-based datasets to analyze the organized convective systems of the central Andes. Previous work has focused on the precipitation climatology and climate dynamics of this region. This study is a unique contribution to our understanding of the characteristics of its precipitating events. Our surface datasets were from field sites in Bolivia where we placed recording gauges in Tuni in the more humid east (Cordillera Real) and in the Nevado Sajama region in the arid west (Cordillera Occidental). The primary space-based dataset was the version 7 TRMM precipitation features database available from the University of Utah. Both the eastern and western cordilleras have similar seasonality with an October-April wet season, peaking in January, and a May-September dry season. The majority of the events recorded at the field sites were light, below $3 \mathrm{~mm} \mathrm{~h}^{-1}$, and short, below $60 \mathrm{~min}$ in duration. Although there were brief periods of heavier rainfall (above $10 \mathrm{~mm} \mathrm{~h}^{-1}$ ), the days with accumulated rainfall above $5 \mathrm{~mm} \mathrm{day}^{-1}$ were more often the result of either multiple light events or longer individual light events rather than heavy rainfall. The $50 \%$ of wet season rainfall at Tuni was contributed by events below $3 \mathrm{~mm} \mathrm{~h}^{-1}$ and $90 \%$ by events below $7 \mathrm{~mm} \mathrm{~h}^{-1}$.

Both the intensity and size of PFs in the study region were analyzed using metrics typical of previous TRMMbased studies and compared to other dry (West Africa), mountainous (Himalayas), and dynamically linked regions (Amazon). The central Andes PF population tended to be more intense in the wet season than in the dry season. The PFs in the coldest $10 \%$ for MIN85 tended to occur more frequently at higher elevations on eastern facing slopes and in areas such as the front ranges of the Altiplano that are characterized by frequent mesoscaleorganized dynamical forcing. With respect to the comparison regions, the central Andes had a distinctly weaker and smaller PF population. No more than $10 \%$ of the PFs in the central Andes met any of the thresholds (MIN85,
MINIR, MAXHT40) used to determine deep convection. Less than $5 \%$ of all PFs in the central Andes were electrified. Even the larger, better organized PFs were less likely to be electrified (9\%) than the global land average, $11.5 \%$ (Liu et al. 2012).

We explored regional variability in the PF population, by stratifying the PF database by the annual rainfall totals into three PF classes, the arid class $\left(<720 \mathrm{~mm} \mathrm{yr}^{-1}\right)$, intermediate class $\left(720-1440 \mathrm{~mm} \mathrm{yr}^{-1}\right)$, and humid class $\left(>1440 \mathrm{~mm} \mathrm{yr}^{-1}\right)$. The arid and intermediate classes had unimodal diurnal cycles peaking in the afternoon with peaks in their rain rate intensity spectra at $1-2 \mathrm{~mm} \mathrm{~h}^{-1}$, with a broader diurnal cycle and rain rate spectrum for the intermediate class. The humid class had a bimodal diurnal cycle and a rain rate spectrum peaking at 3$4 \mathrm{~mm} \mathrm{~h}^{-1}$, suggesting the contribution of better organized PFs that continue developing into the evening hours. In none of the classes was there a significant contribution from events over $10 \mathrm{~mm} \mathrm{~h}^{-1}$. The analysis of the prestorm environments of 2003/04 PFs revealed that for the typical $\mathrm{PF}$ available moisture was limited $(<35 \mathrm{~mm})$ and instability low $\left(<500 \mathrm{~J} \mathrm{~kg}^{-1}\right)$.

Together, the recording gauge data and the spacebased datasets depict the central Andes as a region with primarily short-duration rainfall events characterized by weak, shallow convection. The majority of annual rainfall is contributed by events with light to light-moderate rainfall rates $\left(0.5-4.0 \mathrm{~mm} \mathrm{~h}^{-1}\right)$. These characteristics follow from a largely dry, stable prestorm environment. Although objectively strong, well-organized PFs do occur in the central Andes, they are infrequent and much less important to the surface hydrology of this region than in other tropical regions.

Acknowledgments. We are grateful for the efforts of the University of Utah Precipitation Measuring Mission Science Group (E. Zipser, C. Liu, and colleagues) for the TRMM PF database. We appreciate the various NOAA programs making ENSO, topographic, and reanalysis datasets available, and give many thanks to our incountry colleagues at Universidad Mayor de San Andres (La Paz), National Herbarium of Bolivia, and the Institute of Geological Investigation (IGEMA) who made the collection of historical and field data possible. The paper benefitted from constructive reviews from three anonymous reviewers and useful discussions with Michel Baraer (ETS Montreal), David Cooper (CSU), Anand Gnanadesikan (JHU), Bryan Mark (OSU), and Alexi Russell (JHU). We thank Garik Gutman (HQ NASA), program manager for Land Cover/Land Use Change, for his financial support of our multi-disciplinary project, "The Impact of Disappearing Tropical Andean Glaciers on Pastoral Agriculture" (PI Dan Slayback). 


\section{REFERENCES}

Amitai, E., C. L. Unkrich, D. C. Goodrich, E. Habib, and B. Thill, 2012: Assessing satellite-based rainfall estimates in semiarid watersheds using the USDA-ARS Walnut Gulch gauge network and TRMM PR. J. Hydrometeor., 13, 1579-1588, doi:10.1175/JHM-D-12-016.1.

Balme, M., T. Vischel, T. Lebel, C. Peugeot, and S. Galle, 2006: Assessing the water balance in the Sahel: Impact of small scale rainfall variability on runoff: Part 1: Rainfall variability analysis. J. Hydrol., 331, 336-348, doi:10.1016/j.jhydrol.2006.05.020.

Bao, X., and F. Zhang, 2013: Evaluation of NCEP-CFSR, NCEPNCAR, ERA-Interim, and ERA-40 reanalysis datasets against independent sounding observations over the Tibetan Plateau. J. Climate, 26, 206-214, doi:10.1175/JCLI-D-12-00056.1.

Bendix, J., R. Rollenbeck, and C. Reudenbach, 2006: Diurnal patterns of rainfall in a tropical Andean valley of southern Ecuador as seen by a vertically pointing K-band Doppler radar. Int. J. Climatol., 26, 829-846, doi:10.1002/joc.1267.

— , K. Trachte, J. Cermak, R. Rollenbeck, and T. Nauß, 2009: Formation of convective clouds at the foothills of the tropical eastern Andes (south Ecuador). J. Appl. Meteor. Climatol., 48, 1682-1695, doi:10.1175/2009JAMC2078.1.

Biasutti, M., S. E. Yuter, C. D. Burleyson, and A. H. Sobel, 2012: Very high resolution rainfall patterns measured by TRMM precipitation radar: Seasonal and diurnal cycles. Climate Dyn., 39, 239-258, doi:10.1007/s00382-011-1146-6.

Carvalho, L. M. V., C. Jones, and B. Liebmann, 2004: The South Atlantic convergence zone: Intensity, form, persistence, and relationships with intraseasonal to interannual activity and extreme rainfall. J. Climate, 17, 88-108, doi:10.1175/ 1520-0442(2004)017<0088:TSACZI > 2.0.CO;2.

Cecil, D. J., S. J. Goodman, D. J. Boccippio, E. J. Zipser, and S. W. Nesbitt, 2005: Three years of TRMM precipitation features. Part I: Radar, radiometric, and lightning characteristics. Mon. Wea. Rev., 133, 543-566, doi:10.1175/MWR-2876.1.

Chen, T.-C., S.-P. Weng, and S. Schubert, 1999: Maintenance of austral summertime upper-tropospheric circulation over tropical South America: The Bolivian high-Nordeste low system. J. Atmos. Sci., 56, 2081-2100, doi:10.1175/1520-0469(1999)056<2081: MOASUT > 2.0.CO;2.

Cook, K. H., 2009: South American climate variability and change: Remote and regional forcing processes. Past Climate Variability in South America and Surrounding Regions: From the Last Glacial Maximum to the Holocene, F. Vimeux, F. Sylvestre, and M. Khodri, Eds., Springer, 193-212.

Cosgrove, C. M., and M. Garstang, 1995: Simulation of rain events from rain-gauge measurements. Int. J. Climatol., 15, 10211029, doi:10.1002/joc.3370150908.

Egger, J., and Coauthors, 2005: Diurnal circulation of the Bolivian Altiplano. Part I: Observations. Mon. Wea. Rev., 133, 911-924, doi:10.1175/MWR2894.1.

Espinoza, J. C., M. Lengaigne, J. Ronchail, and S. Janicot, 2012: Large-scale circulation patterns and related rainfall in the Amazon Basin: A neuronal networks approach. Climate Dyn., 38, 121-140, doi:10.1007/s00382-011-1010-8.

Falvey, M., and R. D. Garreaud, 2005: Moisture variability over the South American Altiplano during the South American Low Level Jet Experiment (SALLJEX) observing season. J. Geophys. Res., 110, D22105, doi:10.1029/2005JD006152.

Garreaud, R. D., 1999: Multiscale analysis of the summertime precipitation over the central Andes. Mon. Wea. Rev., 127, 901-921, doi:10.1175/1520-0493(1999)127<0901:MAOTSP>2.0.CO;2.
,2000: Intraseasonal variability of moisture and rainfall over the South American Altiplano. Mon. Wea. Rev., 128, 3337-3346, doi:10.1175/1520-0493(2000)128<3337:IVOMAR > 2.0.CO;2. 2009: The Andes climate and weather. Adv. Geosci., 22, 3-11, doi:10.5194/adgeo-22-3-2009.

and J. M. Wallace, 1998: Summertime incursions of midlatitude air into subtropical and tropical South America. Mon. Wea. Rev., 126, 2713-2733, doi:10.1175/1520-0493(1998)126<2713: SIOMAI $>2.0 . \mathrm{CO} ; 2$.

, M. Vuille, and A. C. Clement, 2003: The climate of the Altiplano: Observed current conditions and mechanisms of past changes. Palaeogeogr. Palaeoclimatol. Palaeoecol., 194, 5-22, doi:10.1016/S0031-0182(03)00269-4.

_, _ , R. Compagnucci, and J. Marengo, 2009: Presentday South American climate. Palaeogeogr. Palaeoclimatol. Palaeoecol., 281, 180-195, doi:10.1016/j.palaeo.2007.10.032.

Giovannettone, J. P., and A. P. Barros, 2009: Probing regional orographic controls of precipitation and cloudiness in the central Andes using satellite data. J. Hydrometeor., 10, 167182, doi:10.1175/2008JHM973.1.

Haile, A. T., T. H. M. Rientjes, E. Habib, V. Jetten, and M. Gebremichael, 2011: Rain event properties at the source of the Blue Nile River. Hydrol. Earth Syst. Sci., 15, 1023 1034, doi:10.5194/hess-15-1023-2011.

Hirose, M., and K. Nakamura, 2005: Spatial and diurnal variation of precipitation systems over Asia observed by the TRMM Precipitation Radar. J. Geophys. Res., 110, D05106, doi:10.1029/ 2004JD004815.

Houze, R. A., 2012: Orographic effects on precipitating clouds. Rev. Geophys., 50, RG1001, doi:10.1029/2011RG000365.

Jomelli, V., V. Favier, A. Rabatel, D. Brunstein, G. Hoffmann, and B. Francou, 2009: Fluctuations of glaciers in the tropical Andes over the last millennium and palaeoclimatic implications: A review. Palaeogeogr. Palaeoclimatol. Palaeoecol., 281, 269 282, doi:10.1016/j.palaeo.2008.10.033.

Lavado Casimiro, W. S., J. Ronchail, D. Labat, J. C. Espinoza, and J. L. Guyot, 2012: Basin-scale analysis of rainfall and runoff in Peru (1969-2004): Pacific, Titicaca and Amazonas drainages. Hydrol. Sci. J., 57, 625-642, doi:10.1080/02626667.2012.672985.

Lenters, J. D., and K. H. Cook, 1997: On the origin of the Bolivian high and related circulation features of the South American climate. J. Atmos. Sci., 54, 656-678, doi:10.1175/1520-0469(1997)054<0656: OTOOTB $>2.0 . \mathrm{CO} ; 2$.

, and _ 1999: Summertime precipitation variability over South America: Role of the large-scale circulation. Mon. Wea. Rev., 127, 409-431, doi:10.1175/1520-0493(1999)127<0409: SPVOSA $>2.0 . \mathrm{CO} ; 2$.

L'Hôte, Y., P. Chevallier, A. Coudrain, Y. Lejeune, and P. Etchevers, 2005: Relationship between precipitation phase and air temperature: Comparison between the Bolivian Andes and the Swiss Alps. Hydrol. Sci. J., 50, 989-997, doi:10.1623/ hysj.2005.50.6.989.

Liebmann, B., G. N. Kiladis, J. Marengo, T. Ambrizzi, and J. D. Glick, 1999: Submonthly convective variability over South America and the South Atlantic convergence zone. J. Climate, 12, 1877-1891, doi:10.1175/1520-0442(1999)012<1877:SCVOSA >2.0.CO;2.

,-- C. S. Vera, A. C. Saulo, and L. M. V. Carvalho, 2004: Subseasonal variations of rainfall in South America in the vicinity of the low-level jet east of the Andes and comparison to those in the South Atlantic convergence zone. J. Climate, 17, 3829-3842, doi:10.1175/1520-0442(2004)017<3829:SVORIS >2.0.CO;2.

Liu, C., 2011: Rainfall contributions from precipitation systems with different sizes, convective intensities, and durations over 
the tropics and subtropics. J. Hydrometeor., 12, 394-412, doi:10.1175/2010JHM1320.1.

— , and E. J. Zipser, 2009: "Warm rain" in the tropics: Seasonal and regional distributions based on $9 \mathrm{yr}$ of TRMM data. J. Climate, 22, 767-779, doi:10.1175/2008JCLI2641.1.

,-- , and S. W. Nesbitt, 2007: Global distribution of tropical deep convection: Different perspectives from TRMM infrared and radar data. J. Climate, 20, 489-503, doi:10.1175/ JCLI4023.1.

,-- D D. J. Cecil, S. W. Nesbitt, and S. Sherwood, 2008: A cloud and precipitation feature database from nine years of TRMM observations. J. Appl. Meteor. Climatol., 47, 27122728, doi:10.1175/2008JAMC1890.1.

—, D. J. Cecil, E. J. Zipser, K. Kronfeld, and R. Robertson, 2012: Relationships between lightning flash rates and radar reflectivity vertical structures in thunderstorms over the tropics and subtropics. J. Geophys. Res. Atmos., 117, D06212, doi:10.1029/2011JD017123.

Mark, B. G., 2008: Tracing tropical Andean glaciers over space and time: Some lessons and transdisciplinary implications. Global Planet. Change, 60,101-114, doi:10.1016/j.gloplacha.2006.07.032.

McCaul, E. W., Jr., C. Cohen, and C. Kirkpatrick, 2005: The sensitivity of simulated storm structure, intensity, and precipitation efficiency to environmental temperature. Mon. Wea. Rev., 133, 3015-3037, doi:10.1175/MWR3015.1.

Mohr, K. I., 2004: Interannual, monthly, and regional variability in the wet season diurnal cycle of precipitation in sub-Saharan Africa. J. Climate, 17, 2441-2453, doi:10.1175/1520-0442(2004)017<2441: IMARVI>2.0.CO;2.

— , and E. J. Zipser, 1996: Mesoscale convective systems defined by their $85-\mathrm{GHz}$ ice scattering signature: Size and intensity comparison over tropical oceans and continents. Mon. Wea. Rev., 124, 2417-2437, doi:10.1175/1520-0493(1996)124<2417: MCSDBT $>2.0 . \mathrm{CO} ; 2$.

Nesbitt, S. W., and A. M. Anders, 2009: Very high resolution precipitation climatologies from the Tropical Rainfall Measuring Mission precipitation radar. Geophys. Res. Lett., 36, L15815, doi:10.1029/2009GL038026.

— E. J. Zipser, and D. J. Cecil, 2000: A census of precipitation features in the tropics using TRMM: Radar, ice scattering, and lightning observations. J. Climate, 13, 4087-4106, doi:10.1175/ 1520-0442(2000)013<4087:ACOPFI > 2.0.CO;2.

- R. Cifelli, and S. A. Rutledge, 2006: Storm morphology and rainfall characteristics of TRMM precipitation features. Mon. Wea. Rev., 134, 2702-2721, doi:10.1175/MWR3200.1.

Nicholls, S. D., and K. I. Mohr, 2010: An analysis of the environments of intense convective systems in West Africa in 2003. Mon. Wea. Rev., 138, 3721-3739, doi:10.1175/2010MWR3321.1.

Nieto-Ferreira, R., and T. M. Rickenbach, 2011: Regionality of monsoon onset in South America: A three-stage conceptual model. Int. J. Climatol., 31, 1309-1321, doi:10.1002/joc.2161.

Nogués-Paegle, J., and K. C. Mo, 1997: Alternating wet and dry conditions over South America during summer. Mon. Wea. Rev., 125, 279-291, doi:10.1175/1520-0493(1997)125<0279: AWADCO $>2.0 . \mathrm{CO} ; 2$.

Perry, L. B., A. Seimon, and G. M. Kelly, 2014: Precipitation delivery in the tropical high Andes of southern Peru: New findings and paleoclimatic implications. Int. J. Climatol., 34, 197-215, doi:10.1002/joc.3679.

Petersen, W. A., S. W. Nesbitt, R. J. Blakeslee, R. Cifelli, P. Hein, and S. A. Rutledge, 2002: TRMM observations of intraseasonal variability in convective regimes over the Amazon.
J. Climate, 15, 1278-1294, doi:10.1175/1520-0442(2002)015<1278: TOOIVI $>2.0 . \mathrm{CO} ; 2$.

Rabatel, A., and Coauthors, 2013: Current state of glaciers in the tropical Andes: A multi-century perspective on glacier evolution and climate change. Cryosphere, 7, 81-102, doi:10.5194/ tc-7-81-2013.

Rapp, J. M., and M. R. Silman, 2012: Diurnal, seasonal, and altitudinal trends in microclimate across a tropical montane cloud forest. Climate Res., 55, 17-32, doi:10.3354/cr01127.

Rasmussen, K. L., and R. A. Houze, 2011: Orogenic convection in subtropical South America as seen by the TRMM satellite. Mon. Wea. Rev., 139, 2399-2420, doi:10.1175/MWR-D-10-05006.1.

Rollenbeck, R., and J. Bendix, 2011: Rainfall distribution in the Andes of southern Ecuador derived from blending weather radar data and meteorological field observations. Atmos. Res., 99, 277-289, doi:10.1016/j.atmosres.2010.10.018.

Romatschke, U., and R. A. Houze, 2010: Extreme summer convection in South America. J. Climate, 23, 3761-3791, doi:10.1175/2010JCLI3465.1.

$\longrightarrow$, and — 2011: Characteristics of precipitating convective systems in the South Asian monsoon. J. Hydrometeor., 12, $3-$ 26, doi:10.1175/2010JHM1289.1.

— , and - 2013: Characteristics of precipitating convective systems accounting for the summer rainfall of tropical and subtropical South America. J. Hydrometeor., 14, 25-46, doi:10.1175/JHM-D-12-060.1.

Ronchail, J., and R. Gallaire, 2006: ENSO and rainfall along the Zongo valley (Bolivia) from the Altiplano to the Amazon basin. Int. J. Climatol., 26, 1223-1236, doi:10.1002/joc.1296.

Salio, P., M. Nicolini, and E. J. Zipser, 2007: Mesoscale convective systems over southeastern South America and their relationship with the South American low-level jet. Mon. Wea. Rev., 135, 1290-1309, doi:10.1175/MWR3305.1.

Seluchi, M. E., and J. A. Marengo, 2000: Tropical-midlatitude exchange of air masses during summer and winter in South America: Climatic aspects and examples of intense events. Int. J. Climatol., 20,1167-1190, doi:10.1002/1097-0088(200008)20:10<1167:: AID-JOC526>3.0.CO;2-T.

- , R. D. Garreaud, F. A. Norte, and A. C. Saulo, 2006: Influence of the subtropical Andes on baroclinic disturbances: A cold front case study. Mon. Wea. Rev., 134, 3317-3335, doi:10.1175/ MWR3247.1.

Siqueira, J. R., and L. A. Toledo Machado, 2004: Influence of the frontal systems on the day-to-day convection variability over South America. J. Climate, 17, 1754-1766, doi:10.1175/ 1520-0442(2004)017<1754:IOTFSO > 2.0.CO;2.

Takemi, T., 2007: A sensitivity of squall-line intensity to environmental static stability under various shear and moisture conditions. Atmos. Res., 84, 374-389, doi:10.1016/j.atmosres.2006.10.001.

Thibeault, J., A. Seth, and G. Wang, 2012: Mechanisms of summertime precipitation variability in the Bolivian Altiplano: Present and future. Int. J. Climatol., 32, 2033-2041, doi:10.1002/joc.2424.

Toracinta, E. R., D. J. Cecil, E. J. Zipser, and S. W. Nesbitt, 2002: Radar, passive microwave, and lightning characteristics of precipitating systems in the tropics. Mon. Wea. Rev., 130, 802-824, doi:10.1175/1520-0493(2002)130<0802:RPMALC >2.0.CO;2.

Vera, C., and Coauthors, 2006: The South American Low-Level Jet Experiment. Bull. Amer. Meteor. Soc., 87, 63-77, doi:10.1175/ BAMS-87-1-63.

Vuille, M., 1999: Atmospheric circulation over the Bolivian Altiplano during dry and wet periods and extreme phases of the Southern Oscillation. Int. J. Climatol., 19, 1579-1600, doi:10.1002/ (SICI)1097-0088(19991130)19:14<1579::AID-JOC441>3.0.CO;2-N. 
_ , and F. Keimig, 2004: Interannual variability of summertime convective cloudiness and precipitation in the central Andes derived from ISCCP-B3 data. J. Climate, 17, 3334-3348, doi:10.1175/1520-0442(2004)017<3334:IVOSCC > 2.0.CO;2.

Wang, J., B. L. Fisher, and D. B. Wolff, 2008: Estimating rain rates from tipping-bucket rain gauge measurements. J. Atmos. Oceanic Technol., 25, 43-56, doi:10.1175/2007JTECHA895.1.

Wolter, K., and M. S. Timlin, 2011: El Niño/Southern Oscillation behaviour since 1871 as diagnosed in an extended multivariate
ENSO index (MEI.ext). Int. J. Climatol., 31, 1074-1087, doi:10.1002/joc.2336.

$\mathrm{Xu}, \mathrm{W} ., 2013$ : Precipitation and convective characteristics of summer deep convection over East Asia observed by TRMM. Mon. Wea. Rev., 141, 1577-1592, doi:10.1175/MWR-D-12-00177.1.

Yang, S., and E. A. Smith, 2008: Convective-stratiform precipitation variability at seasonal scale from $8 \mathrm{yr}$ of TRMM observations: Implications for multiple modes of diurnal variability. J. Climate, 21, 4087-4114, doi:10.1175/2008JCLI2096.1. 